\title{
Ground Water and Streamflow in the Nett Lake Indian Reservation, Northern Minnesota, 1995-97
}

By James F. Ruhl and Gregory A. Payne

U.S. Geological Survey

Open-File Report 98-164

Prepared in cooperation with the

Boise Forte Reservation Tribal Council 


\section{U.S. DEPARTMENT OF THE INTERIOR \\ BRUCE BABBITT, Secretary \\ U.S. GEOLOGICAL SURVEY \\ Thomas J. Casadevall, Acting Director}

The use of firm, trade, and brand names in this report is for identification purposes only and does not constitute endorsement by the U.S. Geological Survey.

For additional information write to:

District Chief

U.S. Geological Survey

2280 Woodale Drive

Mounds View, MN 55112
Copies of this report can be purchased from:

U.S. Geological Survey

Branch of Information Services

Box 25286

Denver, Colorado 80225-0286 


\section{Contents}

Abstract 1

Introduction .1

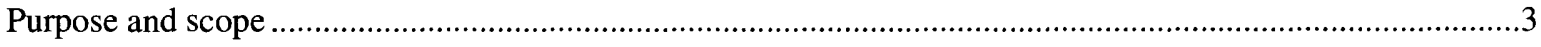

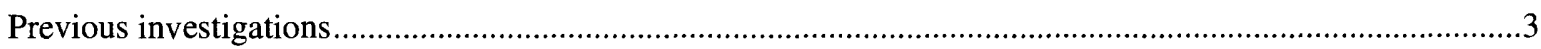

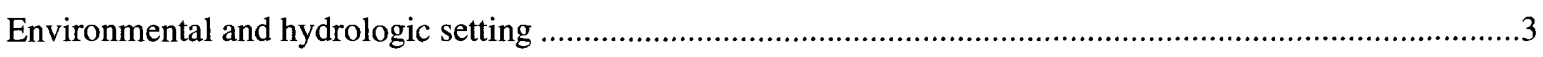

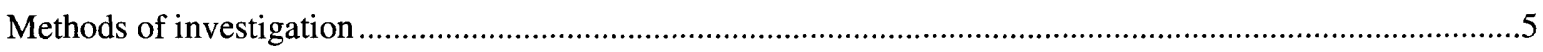

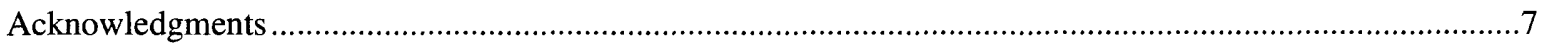

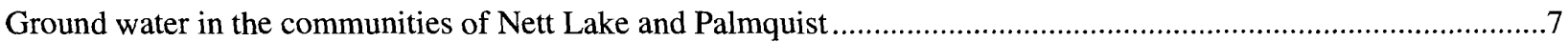

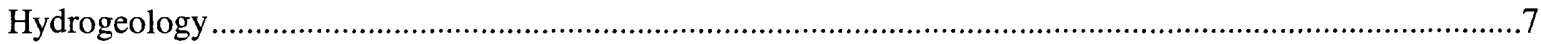

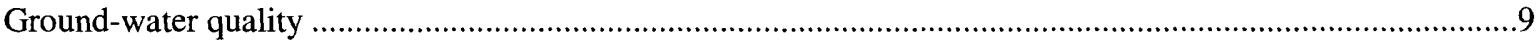

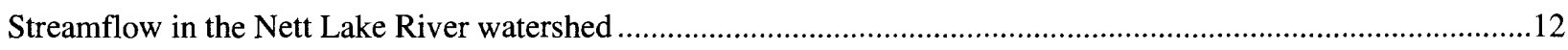

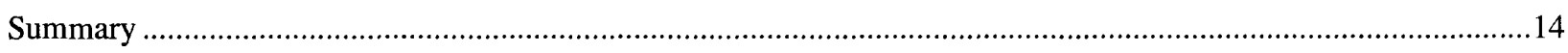

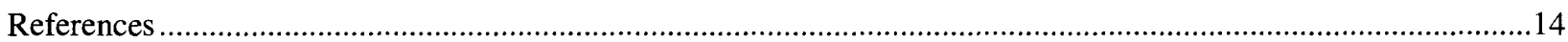

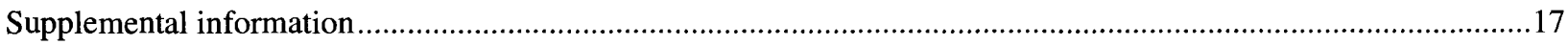

\section{Illustrations}

Figures 1-3. Maps showing:

1. Location of study area and stream gage and peat boring sites, Nett Lake Indian Reservation,

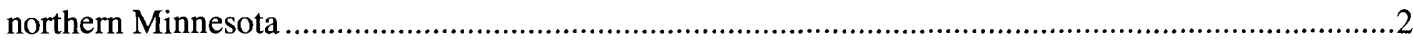

2. Surficial geologic features, Nett Lake Indian Reservation, northern Minnesota ...............................4

3. Locations of wells, test holes, closed landfills, trace of section, and aquifer-test site, Nett Lake Indian Reservation, northern Minnesota.

4. Hydrogeologic section showing water levels, ground-water flow, and lithologic descriptions of drill cuttings along trace A-A' for wells near Nett Lake Community, Nett Lake Indian Reservation, northern Minnesota, August, 1997.

Figures 5-7. Graphs showing:

5. Water-level elevations in six monitoring wells and three community wells, Nett Lake Indian Reservation, northern Minnesota

6. Major-ion composition of water samples from wells completed in sand and gravel aquifers and bedrock aquifers, Nett Lake Indian Reservation, northern Minnesota, 1995-96.

7. Daily mean stream discharge for Nett Lake River and Woodduck Creek, near Nett Lake Community, Nett Lake Indian Reservation, northern Minnesota.

\section{Tables}

1. Geologic logs of six monitoring wells, five community wells, three test holes, and seven lakebed borings in Nett Lake, Nett Lake Indian Reservation, northern Minnesota, 1995-96.

2. Physical and chemical properties, major and minor ions, and nutrients in water samples from wells in the Nett Lake Indian Reservation, northern Minnesota, 1995-96.

3. Trace metals in water samples from wells in the Nett Lake Indian Reservation, northern Minnesota, 1995-96..27

4. Volatile organic compounds in water samples from wells in the Nett Lake Indian Reservation, northern Minnesota, 1995-96 


\section{Tables--Continued}

5. Volatile organic compounds not detected in water samples from wells in the Nett Lake Indian Reservation, northern Minnesota, 1995-96

6. Discharge for the Nett Lake River near Nett Lake Community, and summary statistics of the discharge, during the 1996 and 1997 water years (October 1, 1995 - September 30, 1997), Nett Lake Indian Reservation, northern Minnesota

7. Discharge for Woodduck Creek near Nett Lake Community, and summary statistics of the discharge, during the 1996 and 1997 water years (October 1, 1995 - September 30, 1997), Nett Lake Indian Reservation, northern Minnesota...

8. Instantaneous streamflow in Lost River, and daily mean streamflow in Woodduck Creek and Nett Lake River, near Nett Lake Community, Nett Lake Indian Reservation, northern Minnesota. 


\section{Conversion Factors, Vertical Datum, and Abbreviated Water-Quality Units}

\section{Multiply inch-pound unit}

inch (in)

foot $(\mathrm{ft})$

acre $(\mathrm{ac})$

square mile $\left(\mathrm{mi}^{2}\right)$

cubic foot per second $\left(\mathrm{ft}^{3} / \mathrm{s}\right)$

gallon per minute (gal/min)

foot squared per day $\left(\mathrm{ft}^{2} / \mathrm{d}\right)$

degrees Fahrenheit $\left({ }^{\circ} \mathrm{F}\right)$
By

2.54

0.3048

0.004047

259.0

0.02832

0.06309

0.09290

$$
{ }^{\circ} \mathrm{C}=\left({ }^{\circ} \mathrm{F}-32\right) / 1.8
$$

To obtain metric unit

centimeter

meter

square kilometer

hectare

cubic meter per second

liter per second

meter squared per day

degrees Celsius $\left({ }^{\circ} \mathrm{C}\right)$

Concentrations of chemical constituents in water samples are given in milligrams per liter $(\mathrm{mg} / \mathrm{L})$, micrograms per liter $(\mu \mathrm{g} / \mathrm{L})$, and milliequivalents per liter $(\mathrm{mEq} / \mathrm{L})$. Milligrams per liter is a unit that expresses the concentration of a chemical constituent in solution as the mass (milligrams) of the constituent per unit volume (liter) of water. One milligram per liter is equivalent to one thousand micrograms per liter. Concentrations of chemical constituents in $\mathrm{mg} / \mathrm{L}$ and $\mu \mathrm{g} / \mathrm{L}$ are reported as dissolved (operationally defined as the amount of a constituent in a water sample that passes through a 0.45 -micrometer membrane filter). (Concentrations of phosphorus also are reported as total, which is the amount of the constituent in an unfiltered sample.)

Sea level: In this report, sea level refers to the National Geodetic Vertical Datum of 1929 (NGVD of 1929)-geodetic datum derived from a general adjustment of the first-order level nets of both the United States and Canada, formerly called Sea Level Datum of 1929. 


\section{Glossary}

The geologic and hydrologic terms pertinent to this report are defined as follows:

Alkalinity: Capacity for neutralizing acid and commonly reported as an equivalent amount of calcium carbonate. This property is attributed mostly to bicarbonate if the $\mathrm{pH}$ of the water is less than 9.5 .

Aquifer: Geologic or stratigraphic unit that contains sufficient saturated, permeable material to yield usable quantities of water to wells or springs.

Confined aquifer: An aquifer for which the saturated zone is bounded by confining beds such as clay layers; also referred to as a buried aquifer. Water levels in tightly cased wells completed in this type of aquifer rise above the top of the aquifer.

Conglomerate: Coarse grained, sedimentary rock derived from fragments of other rock.

Crystalline bedrock: Igneous or metamorphic bedrock, as opposed to sedimentary bedrock.

Discharge: The volume of water that passes a through a given cross-sectional area at a fixed point within a given period of time.

Dissolved solids: Total amount of mineral constituents dissolved in water.

Granite: Very hard igneous rock composed primarily of quartz and feldspar.

Graywacke: Generally dark colored, hard, poorly-sorted, argillaceous sandstone.

Ground water: Subsurface water in the saturated zone.

Igneous rock: Rock solidified from molten or partly molten material.

Intrusives: Igneous rocks formed within existing rock by the injection of magma into cracks.

Lava: A general term for molten or partially molten volcanic material; rocks formed from solidification of lava include basalts and rhyolites.

Outwash: Sorted and stratified sand and gravel deposited by flowing meltwater from glacier ice.

Maximum Contaminant Level (MCL): A regulatory limit that pertains to the safety of drinking water.

Metamorphic rock: Rock derived from pre-existing rocks by mineralogical, chemical, and structural changes, essentially in the solid state, in response to changes in temperature, pressure, shearing stress, and chemical environment at depth in the earth's crust.

Peat: Unconsolidated, dark colored deposits of organic material; typically present in a water-saturated environment such as a wetland or bog.

pH: A measure of the hydrogen ion activity (concentration) of a solution; equal to the negative logarithm of the concentration of hydrogen ions. A solution with a $\mathrm{pH}$ of 7.0 is neutral; a solution with a $\mathrm{pH}$ less than 7.0 is acidic; and a solution with a $\mathrm{pH}$ greater than 7.0 is basic.

Slate: A compact, fine-grained metamorphic rock typically formed from mud or volcanic ash.

Secondary Maximum Contaminant Level (SMCL): A non-regulatory guideline that pertains to aesthetic properties of drinking water, such as taste, odor, color, and staining potential.

Specific capacity: The yield of a well per unit of drawdown.

Specific conductance: The capacity of water to conduct an electric current. This property generally is proportional to the dissolved solids content in most dilute natural water.

Streamflow: The discharge in a surface stream. 
Till: Unsorted and unstratified clay, silt, sand, gravel, pebbles, and boulders of glacial origin.

Transmissivity: A measure of the capacity of an aquifer to transmit water. It is equal to the hydraulic conductivity multiplied by the saturated thickness of the aquifer.

Tuff: Porous rock, typically stratified, formed by consolidation of volcanic ash.

Unconfined aquifer: An aquifer for which the saturated zone is not bounded by confining beds such as clay layers; also referred to as surficial or water-table aquifer. Water levels in wells completed in this type of aquifer rise and decline within the aquifer.

Volatile organic compounds (VOC): Carbon-containing chemicals that readily evaporate at normal air temperature and pressure. These chemicals are contained in commercial products such as gasoline, paints, adhesives, solvents, wood preservatives, pesticides, cosmetics, and refrigerants. High concentrations in drinking water can be toxic to humans. 


\title{
Ground Water and Streamflow in the Nett Lake Indian Reservation, Northern Minnesota, 1995-97
}

\section{By James F. Ruhl and Gregory A. Payne}

\begin{abstract}
The Nett Lake Indian Reservation, about 164 square miles in area, is in northern Minnesota. About 300 people live in Nett Lake Community, about 100 people live in Palmquist Community, and a few people live in other parts of the Reservation. Water resources in the Reservation include: (1) ground water in sand and gravel aquifers and bedrock aquifers; (2) Nett Lake; (3) streams in the Nett Lake River watershed; and (4) wetlands that comprise about one-half of the area of the Reservation.

Ground-water sources in the Reservation consist of sand and gravel aquifers and bedrock aquifers. Buried sand and gravel aquifers are important sources of water. Reported yields for wells completed in these aquifers are as much as 60 gallons per minute. Reported yields for wells completed in bedrock aquifers are as much as 34 gallons per minute.

The Reservation is located within the Little Fork River Basin. Streams that flow into and out of Nett Lake are in the Nett Lake River watershed, a subbasin of the Little Fork River Basin. Most of the discharge into Nett Lake is from Lost River and Woodduck Creek; a small amount of discharge into Nett Lake is from several other small streams. Discharge from Nett Lake is to the Nett Lake River.

Ground water in buried sand and gravel aquifers in the vicinity of three community wells and a closed landfill east of Nett Lake Community may have moved from the landfill toward the community wells. Ground water near Nett Lake locally discharged into the lake through underlying peat that ranges in thickness from 3 to 12 feet. Two Palmquist Community wells probably are not hydraulically connected to shallow ground water in the vicinity of a nearby closed landfill. The wells are located more than 2,000 feet away and are completed in a bedrock aquifer overlain by 124-154 feet of clay.

The concentrations of the trace metals iron and manganese exceeded their respective U.S. Environmental Protection Agency Secondary Maximum Contaminant Level limits in water from three and six wells sampled, respectively. All but 3 of 63 VOCs (volatile organic compounds) analyzed for in water from seven wells sampled had concentrations less than the MDL (method detection limit) of $0.2000 \mu \mathrm{g} / \mathrm{L}$ except for di-bromo-chloro-propane, which had a concentration less than the MDL of $1.000 \mu \mathrm{g} / \mathrm{L}$. The detected VOCs were phenols, benzene, and 1,1dichloroethane. The sources of these VOCs may have been leachate from nearby closed landfills. Benzene, the only one of the three detected VOCs with an established MCL (Maximum Contaminant Level), had a concentration that was one order of magnitude less than its MCL of $5 \mu \mathrm{g} / \mathrm{L}$.
\end{abstract}

The stage-discharge relations for Nett Lake River and Woodduck Creek were usable for estimation of daily mean discharge for each stream. Six discharge measurements made in the Lost River indicate that discharge in this stream could be substantially greater or smaller than concurrent discharge in Woodduck Creek.

\section{Introduction}

The Nett Lake Indian Reservation (hereinafter referred to as the Reservation), about $164 \mathrm{mi}^{2}(105,000$ acres) in area, is in northern Minnesota (fig. 1). About 80 percent of the Reservation is in Koochiching County; the remainder is in St. Louis County. About 300 people live in Nett Lake Community and about 100 people live in Palmquist Community; a small number of people live in other parts of the Reservation (Dr. Chris Holm, Reservation Biologist, oral commun., 1997).

The U.S. Geological Survey (USGS) and the Boise Forte Reservation Tribal Council cooperated in a study of the water resources of the Reservation during 199597. These resources include: (1) ground water in sand and gravel aquifers and bedrock aquifers; (2) Nett Lake; 


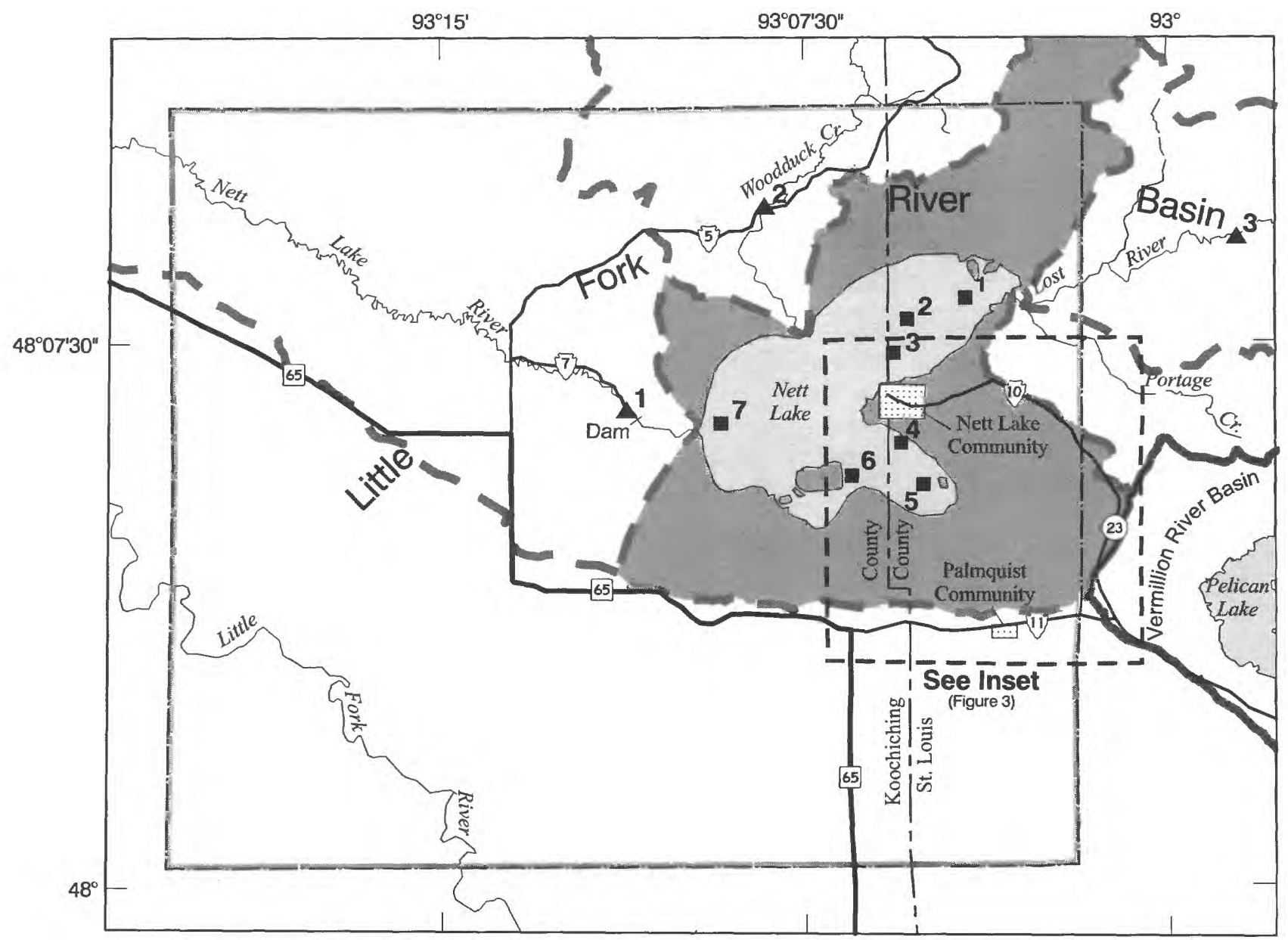

Base from U.S. Geological Survey

Digital data, 1:100,000, 1985

U.S. Albers projection

\section{EXPLANATION}

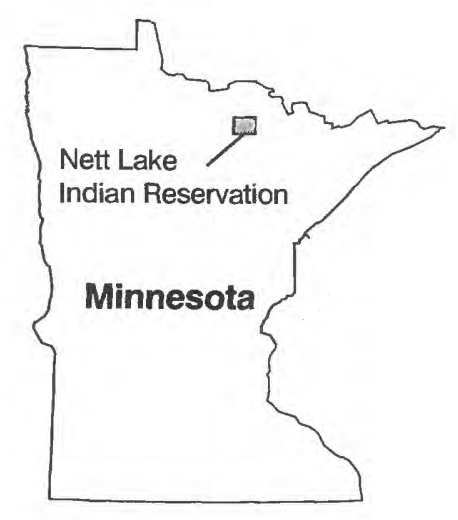

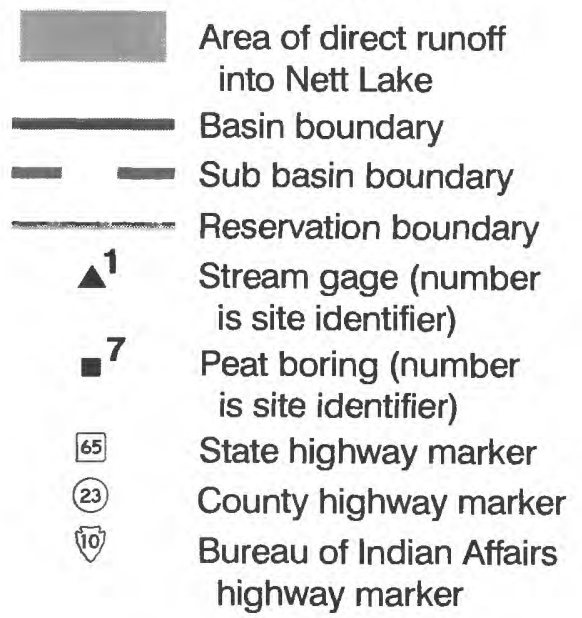

Figure 1. Location of study area and stream gage and peat boring sites, Nett Lake Indian Reservation, northern Minnesota. 
(3) streams in the Nett Lake River watershed; and (4) wetlands that comprise about one-half the area of the Reservation. The study provides information to tribal officials for effective management of these resources and improved understanding of the hydrology of the area.

Concerns of tribal officials about the Reservation's water resources include: (1) potential ground-water contamination from two closed landfills —one each near Nett Lake and Palmquist Communities; (2) occasional dewatering of aquifers that supply community wells (Dr. Chris Holm, Reservation Biologist, oral commun., 1997); and (3) maintenance of the depth and quality of Nett Lake to optimize production of wild rice - an important food resource in the diet, culture, and economy of the Reservation - and to provide a suitable staging area for migratory waterfowl.

\section{Purpose and Scope}

The purposes of this report are to describe: (1) hydrogeologic conditions and ground-water quality in the communities of Nett Lake and Palmquist; and (2) streamflow in the Nett Lake River watershed. Hydrogeologic conditions are described mainly in terms of: (1) water-bearing characteristics of the sand and gravel aquifers and bedrock aquifers; (2) local flow directions of shallow ground water near the two closed landfills; and (3) local ground-water interaction with Nett Lake. Ground-water quality is described on the basis of chemical analyses of water from wells completed in the sand and gravel aquifers and bedrock aquifers. Streamflow is described on the basis of direct measurements of discharge and estimates of daily mean discharge derived from stage and discharge records.

Data analyzed and presented in this report were compiled from: (1) geologic logs of glacial sediments and bedrock recorded for six monitoring wells, five community wells, and three test holes; (2) lakebed borings at seven sites in Nett Lake; (3) water-level measurements for six monitoring wells and three community wells; (4) the specific capacity of a Nett Lake Community well; (5) water-quality analyses of samples from six monitoring wells and two community wells; and (6) stage and discharge measurements from the Nett Lake River, Lost River, and Woodduck Creek.

\section{Previous Investigations}

Information about the ground-water resources of the Reservation is available from a report by Norvitch (1963) that describes the geologic setting and hydrogeologic characteristics of the aquifers and the quality of the ground water. Information about the hydrologic balance of Nett Lake is available from an engineering study of water-level control of Nett Lake (TKDA and Associates, Incorporated, written communication, 1988). A general appraisal of the water resources of the Little Fork River Basin, which includes the study area, has been published as a hydrologic atlas (Helgesen and others, 1976).

\section{Environmental and Hydrologic Setting}

The climate is continental; the normal monthly (30year average) temperature ranges from about $0^{\circ} \mathrm{F}$ during January to about $66^{\circ} \mathrm{F}$ during July (Baker and others, 1985). The normal annual (30-year average) total precipitation is about 27 inches (Baker and Kuehnast, 1978). About 20 percent of the total precipitation is in the form of snow (Helgesen and others, 1976).

The principal geologic materials in the Reservation are: (1) Proterozoic-age, igneous and metamorphic bedrock, consisting of Vermilion Granite (generally light-colored intrusives) and the Knife Lake Group (slates, graywackes, tuffs, lavas, and conglomerate); (2) Pleistocene-age, unconsolidated glacial sediments, consisting of morainal till, lake clay and lake sand, and, in scattered areas, outwash sand and gravel; and (3) Holocene-age (post-glacial), unconsolidated sediments that consist of alluvial sand and gravel along the Little Fork River, and peat within wetlands and bed sediments of Nett Lake (Norvitch and others, 1963).

The areal extent of exposed bedrock, major glacial features, and post-glacial alluvium and peat are shown in figure 2. The mapped glacial features include: (1) a ground moraine of St. Louis sublobe origin that mostly consists of buff- to gray-colored, calcareous till with carbonate rock fragments; (2) an end moraine of Rainy lobe origin that mostly consists of gray till with associated outwash; (3) lake and beach sand originally deposited in the littoral zone of Glacial Lake Agassiz; and (4) outwash sand and gravel believed to be of Rainy lobe origin (Norvitch and others, 1963).

The sources of ground water in the Reservation are sand and gravel aquifers and bedrock aquifers. The sand and gravel aquifers are composed of surficial (unconfined) and buried (confined) alluvium, lake and beach sand, and outwash. Most surficial sand and gravel aquifers occur in outwash; most buried sand and gravel aquifers occur as lenses of sand and gravel within end 

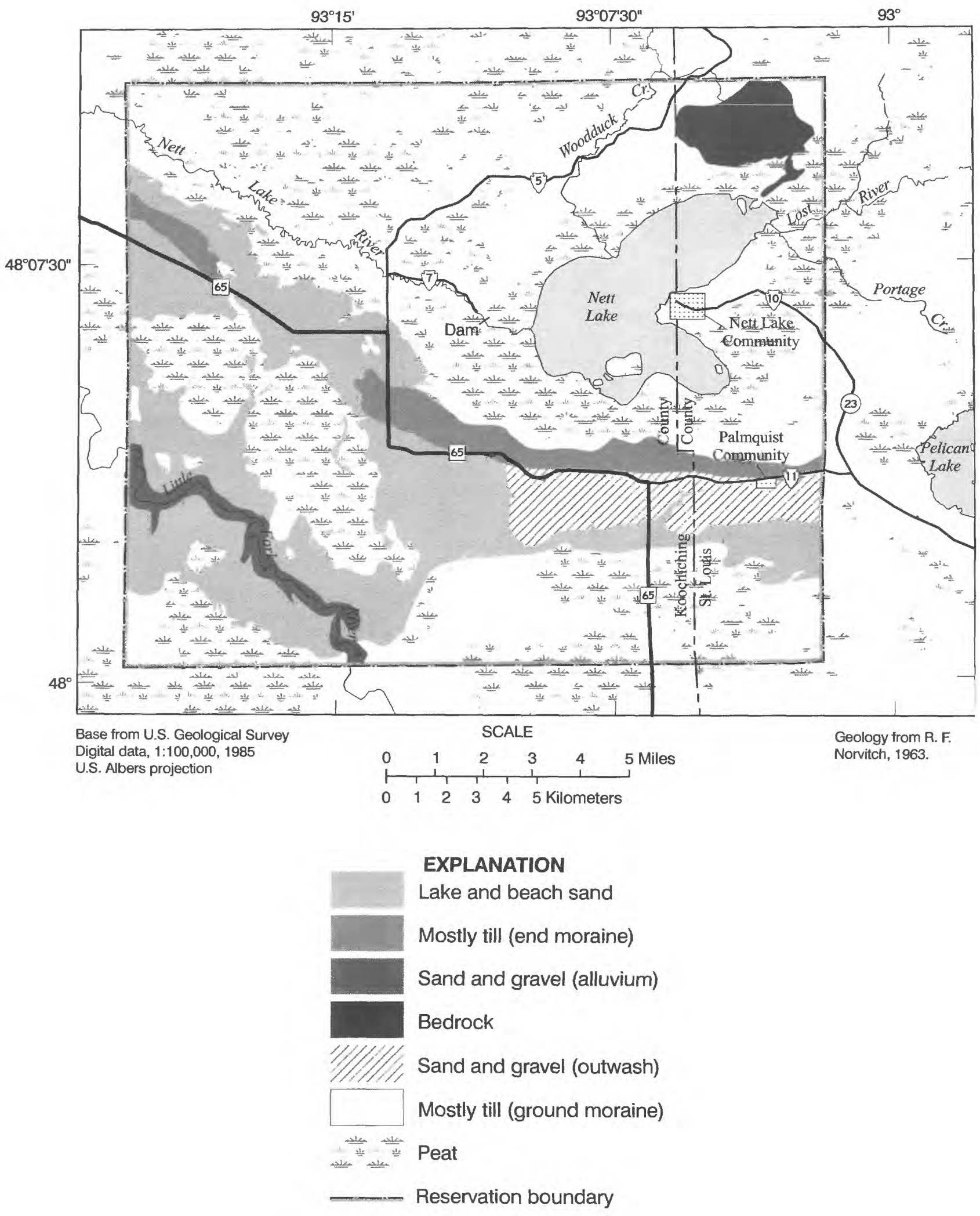

Figure 2. Surficial geologic features, Nett Lake Indian Reservation, northern Minnesota. (Only peat mapped outside Reservation boundary) 
and ground moraines. The bedrock aquifers are composed of fractured zones of the bedrock.

The buried sand and gravel aquifers are water-supply sources near Nett Lake Community. The report by Norvitch (1963) and results of test drilling for watersupply wells indicate that the buried sand and gravel aquifers are small and discontinuous. The productivity of the bedrock aquifers is limited by the density of fractures. Exposed surfaces of bedrock in the northeast part of the Reservation are not fractured (Norvitch, 1963).

The Reservation is located within the Little Fork River Basin (fig. 1). Surface-water drainage from about the southwestern 40 percent of the Reservation flows out the Little Fork River toward the northwest; surfacewater drainage from the remainder of the Reservation flows out the Nett Lake River toward the northwest. Streams that flow into and out of Nett Lake are in the Nett Lake River watershed, a subbasin of the Little Fork River Basin. Most of the streamflow into Nett Lake is from Lost River and Woodduck Creek; a small amount of streamflow into Nett Lake is from several other small streams. All streamflow from Nett Lake is to the Nett Lake River.

Streamflow in the Reservation is sustained during periods of low flow by ground-water discharge and drainage from lakes (Helgesen and others, 1976). High streamflow is regulated by the storage and release of water from wetlands and lakes. High streamflow accompanies or immediately follows spring snowmelt, but may also result from high-intensity rainfall.

The principal ions in the ground water are calcium, magnesium, and bicarbonate (Helgesen and others, 1976). Areal variations in the concentrations of these ions is attributable to differences in mineralogic composition of the glacial sediments and bedrock; ground-water residence time; and chemical composition of the recharge. The quality of the ground water for household use may be lowered because of the hardness and concentrations of iron and manganese that exceed $300 \mu \mathrm{g} / \mathrm{L}$ and $50 \mu \mathrm{g} / \mathrm{L}$, respectively. Problems associated with the lowered water quality include unpleasant tastes and odors, staining of fixtures, and buildup of deposits in sinks and bathtubs.

\section{Methods of Investigation}

Six monitoring wells (MW) installed by the USGS, five community wells $(\mathrm{CW})$ installed by the Reservation, and three test holes (TH) drilled by the
USGS, were used in the collection of hydrogeologic and water-quality data (fig. 3 ). These wells were completed in sand and gravel aquifers except CW4 and CW5, which were completed in bedrock.

Detailed descriptions of the construction methods for the monitoring wells are described by Menheer and Brigham (1997). The boreholes were drilled with a hollow-stem rotary hydraulic auger drill rig. The casings are flush-threaded, 2-inch inside-diameter, PVC (polyvinyl chloride). The screens are 5-ft-long (except for MW5, which is 10-ft-long), flush-threaded, machine slotted (0.010-slot) PVC. The boreholes around the screens were backfilled with washed, medium to coarse sand. Bentonite grout was pumped into the annular space above the sand packs to within 3-4 ft of land surface. A 7-ft-long protective steel casing was cemented in place around each well head to divert surface drainage.

Water levels in MW1-MW6 and in CW1-CW3 were measured with an electric tape. The reference point elevations (above sea level) for MW1-MW4 were surveyed to within 0.01 foot from established benchmarks. The reference point elevations for MW5 and MW6 and the community wells were estimated to within 5 feet from USGS topographic maps.

Seven borings through lakebed peat into underlying lake clay were done during winter in Nett Lake (fig. 1). The borings were done by hand-driving, from the ice surface, 6 - to 12 -ft lengths of 1.25 -inch inside-diameter steel pipe with a 6-inch drive-point screen through the peat and into a few inches of the underlying clay. Thicknesses of the peat were determined from these borings.

Ground-water samples were collected for chemical analyses from MW1-MW6 and from CW3 and CW4. Prior to collection of these samples, water was pumped for about 20 to 40 minutes to remove at least three well casing volumes of water. CW3 and CW4 had permanently installed, submersible pumps. MW1MW6 were pumped with a portable, positive displacement Keck pump. During the pumping period the water was monitored to determine temperature, $\mathrm{pH}$, specific conductance, and dissolved oxygen concentration. These measurements were made with a Hydrolab sonde calibrated at the start of each sampling day. When these properties stabilized, the water from the well was assumed to represent the water in the aquifer, and a sample was collected. Detailed descriptions of the procedures used to collect, treat, and store the samples are described by Fishman and 

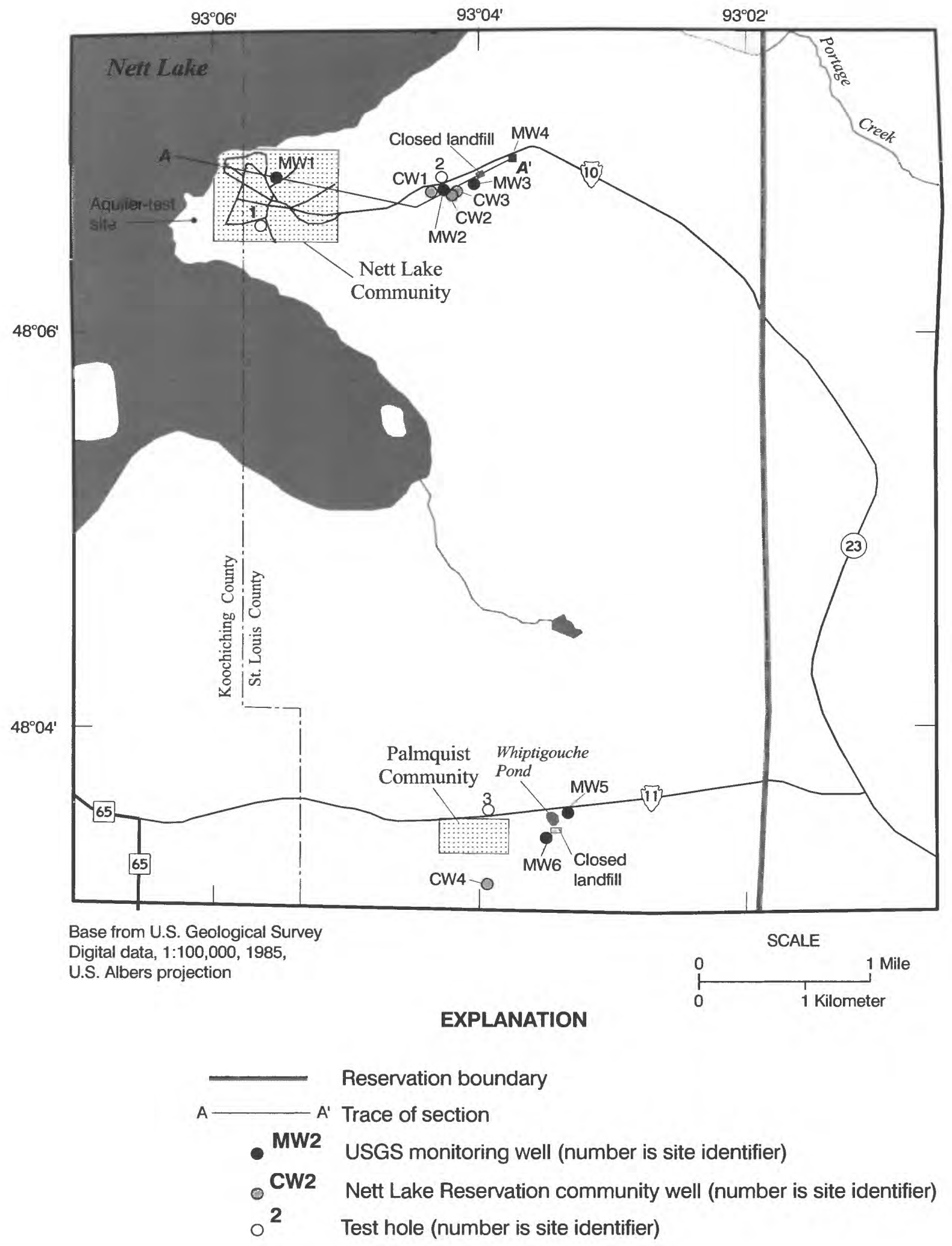

Figure 3. Locations of wells, test holes, closed landfills, trace of section, and aquifer-test site, Nett Lake Indian Reservation, northern Minnesota. 
Friedman (1989) and Koterba and others (1995). Chemical analyses of the samples were done at the USGS National Water Quality Laboratory in Arvada, Colorado.

Ions, nutrients, and 21 trace metals were analyzed in water sampled once from MW2, MW4, MW5, MW6, and CW4, and in water sampled twice from MW3 and CW3. Only nutrients were analyzed in water sampled once from MW1. A total of 63 VOCs were analyzed in water sampled once from MW2, MW4, MW5, MW6, and CW4, in water sampled twice from CW3, and in water sampled three times from MW3.

A blank water sample was analyzed for the same ions and trace metals and for some of the same VOCs (benzene, toluene, ethyl-benzene, xylene, meta/paraxylene, and tertiary-butyl-methyl-ether) as water from the wells sampled (environmental water samples) to verify quality of data. The blank water sample was collected under similar conditions and with similar equipment as the environmental water samples to determine if contamination occurred between samples. These quality-assurance analyses indicated that the reported concentrations of constituents analyzed in this study, except possibly fluoride, were not affected by contamination between sample sites.

Detectable concentrations of fluoride $(0.2 \mathrm{mg} / \mathrm{L})$, calcium $(0.06 \mathrm{mg} / \mathrm{L})$, copper $(60 \mu \mathrm{g} / \mathrm{L})$, silver $(1 \mu \mathrm{g} / \mathrm{L})$, and toluene $(0.144 \mu \mathrm{g} / \mathrm{L})$ were reported for the blank water sample. Fluoride and calcium were the only two of these constituents that were present above the MDL (method detection limit- the minimum concentration that can be reliably cited) in water from the wells sampled. The concentrations of calcium in water from the wells sampled were about two orders of magnitude greater than that reported for the blank water sample. The concentration of fluoride in water from three wells sampled, however, was the same as that reported for the blank water sample.

Stream-discharge data were collected from the Nett Lake River, Lost River, and Woodduck Creek (fig. 1). Stream-gage sites on the Nett Lake River and Woodduck Creek were instrumented for collection of continuous stage data during the open-water part of the year. The site on Lost River was equipped with a staff gage for manual readings of stage. Current meters were used to measure discharge at 4- to 6-week intervals at all gage sites. Stage-discharge relations were developed for the gage sites on Nett Lake River and Woodduck Creek by procedures described in Rantz (1982). Daily mean discharges for these streams were computed from recorded stage and their respective stage-discharge relations using methods described in Kennedy (1983).

\section{Acknowledgments}

We are grateful to Dr. Chris Holm, Boise Forte Reservation Biologist, and other members of the Boise Forte Reservation Tribal Council, for the administrative and field support given to the study. This support included assistance in the location of and access to monitoring-well and stream-gage sites and community wells, and assistance in the lakebed borings that were done in Nett Lake.

\section{Ground water in the Communities of Nett Lake and Palmquist}

Evaluation of ground water in the Nett Lake Indian Reservation focused on the communities of Nett Lake and Palmquist. Residents of the Reservation use ground water from aquifers in or near these communities for their source of water supply. Closed landfills near these communities are potential sources of ground-water contamination.

\section{Hydrogeology}

Till that consists predominantly of clay with some fine to coarse sand is present in and around the community of Nett Lake (table 1, back of the report). These sediments are not aquifers except in a few locations where water-bearing layers of sand and gravel are buried within the till. Nett Lake Community wells are completed in these sand and gravel aquifers. Reported yields for CW1, CW2, and CW3 were about 12,36 , and $60 \mathrm{gal} / \mathrm{min}$, respectively (Dr. Chris Holm, Reservation Biologist, oral commun., 1997).

Water-level elevations in MW2, MW3, MW4, CW1, CW2, and CW3 near the closed landfill east of Nett Lake Community indicate a moderate hydraulic gradient of about $12 \mathrm{ft}$ per mile from MW3, located along the edge of the closed landfill, to MW2, located near the three community wells (fig. 4). The gradient, which may have been influenced by ground-water withdrawals from the community wells, suggests the potential for local ground water to have moved through shallow glacial sediments from the closed landfill toward the community wells. The rate of the groundwater movement would have been dependent on the degree of interconnection of sand and gravel lenses within the till.

The transmissivity of a buried sand and gravel aquifer, estimated by the method of Theis and others 
䲻
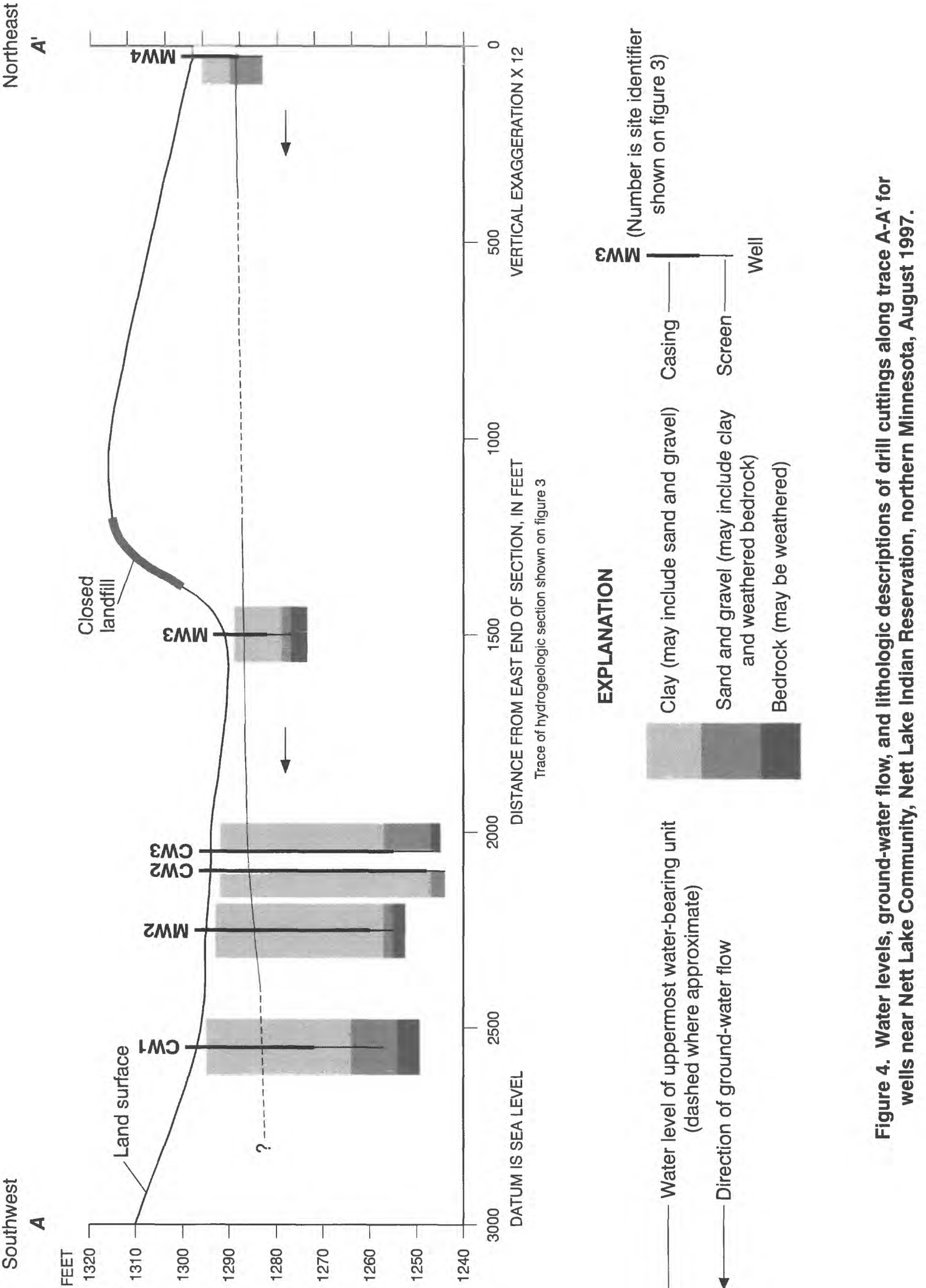
(1963) from the specific capacity for CW3, was about $1,600 \mathrm{ft}^{2} / \mathrm{d}$. The transmissivity of a buried sand and gravel aquifer, estimated from an aquifer test west of Nett Lake Community (fig. 1), was about $800 \mathrm{ft}^{2} / \mathrm{d}$ (Norvitch, 1963). These estimated transmissivities are in the low part of the range $\left(1,000\right.$ to $\left.16,000 \mathrm{ft}^{2} / \mathrm{d}\right)$ reported for other buried sand and gravel aquifers in western Minnesota (Delin, 1986). The estimated transmissivities indicate that these aquifers may not supply a sufficient amount of water to support large capacity wells.

The water-level elevation in MW1 near the shore of Nett Lake was about 9-11 ft higher than the lake (fig. 5), which indicated that shallow ground water locally discharged into the lake through underlying peat. The thickness of the peat, determined from lakebed borings, ranges from 3 to 12 feet (table 1, back of the report). Tightly compacted, gray lake clay underlies the peat. The steep hydraulic gradient (about 25-35 ft per mile) between MW1 and Nett Lake may indicate that the low permeability of the peat and underlying clay restricts ground-water discharge into the lake.

The two Palmquist Community wells (CW4 and CW5) are completed in the bedrock aquifer. The reported yields for CW4 and CW5 were $34 \mathrm{gal} / \mathrm{min}$ and $26 \mathrm{gal} / \mathrm{min}$, respectively. These community wells probably are not hydraulically connected to shallow ground water in the vicinity of the closed landfill east of the community because the wells are located more than 2,000 feet away and the bedrock is overlain by 124-154 feet of clay. Water-level elevations were about 7-13 ft higher in MW6 than MW5 (fig. 5), which suggests that local ground-water movement in the shallow glacial sediments near the closed landfill was not toward the community wells.

\section{Ground-Water Quality}

The diagrams in figure 6 show that water from the wells sampled was of the calcium magnesium bicarbonate type. The sizes of the diagrams are relative to major-ion concentration (Hem, 1985). The sizes of the diagrams were similar except for MW5 and CW4, which were slightly smaller, thus indicating that water from these two wells had a smaller major-ion concentration than water from the other wells sampled.

The $\mathrm{pH}$ of water from eight wells sampled ranged from 6.1 to 7.7 (table 2, back of the report). These $\mathrm{pH}$ values were within the range of 6.0 to 8.5 that is typical of most ground water in the United States (Hem, 1985), and also were within the SMCL range of 6.5 to 8.5 established by the USEPA (U.S. Environmental Protection Agency) (1996) except for field measurements of 6.4 and 6.1 for MW1 and CW3, respectively. The concentrations of sulfate, chloride, and fluoride in water from seven wells sampled also were less than their USEPA (1966) SMCL limits $(250,250$, and $2.0 \mathrm{mg} / \mathrm{L}$, respectively).

The concentrations of nitrate (as nitrogen) in water from eight wells sampled were less than the MCL of 10 $\mathrm{mg} / \mathrm{L}$ for drinking water established by the USEPA (1996). These concentrations were less than what generally is considered a natural background of 3.0 $\mathrm{mg} / \mathrm{L}$ in ground water (Madison and Brunett, 1984).

The concentrations of 21 trace metals in water from seven wells sampled were present in minute concentrations that generally were less than $1,000 \mu \mathrm{g} / \mathrm{L}$ (table 3, back of the report). These concentrations are typical of most natural ground water (Hem, 1985). Natural sources of trace metals include leachate from soil and decayed plant material, solutes from minerals in glacial sediments and igneous and metamorphic rocks, and precipitation.

The concentrations of 10 trace metals with established MCLs in water from the seven wells sampled were within their respective regulatory limits. The 10 trace metals and their USEPA (1996) MCLs are antimony $(6 \mu \mathrm{g} / \mathrm{L})$, arsenic $(50 \mu \mathrm{g} / \mathrm{L})$, barium $(2,000$ $\mu \mathrm{g} / \mathrm{L})$, beryllium $(4 \mu \mathrm{g} / \mathrm{L})$, cadmium $(5 \mu \mathrm{g} / \mathrm{L})$, chromium $(100 \mu \mathrm{g} / \mathrm{L})$, lead $(15 \mu \mathrm{g} / \mathrm{L})$, mercury (2 $\mu \mathrm{g} / \mathrm{L})$, nickel $(100 \mu \mathrm{g} / \mathrm{L})$, and selenium $(50 \mu \mathrm{g} / \mathrm{L})$. The concentrations of two of five trace metals with established SMCLs, however, exceeded their respective guidelines in water from six of the seven wells sampled (MW2, MW3, MW4, MW5, CW3, and CW4). The five trace metals and their USEPA (1996) SMCLs are iron $(300 \mu \mathrm{g} / \mathrm{L})$, manganese $(50 \mu \mathrm{g} / \mathrm{L})$, copper $(1,000 \mu \mathrm{g} / \mathrm{L})$, silver $(100 \mu \mathrm{g} / \mathrm{L})$, and zinc $(5,000 \mu \mathrm{g} / \mathrm{L})$. Concentrations of iron ranged from 590 to $1,400 \mu \mathrm{g} / \mathrm{L}$ in water sampled from MW2, CW3, and CW4. Potential sources of the iron include dissolution of igneous and metamorphic rock minerals such as pyroxenes, amphiboles, biotite, and magnetite, and in the case of water sampled from CW3 and CW4, corrosion of the steel well casings. Concentrations of manganese ranged from 55 to 1,500 $\mu \mathrm{g} / \mathrm{L}$ in water from MW2, MW3, MW4, MW5, CW3, and CW4. Potential sources of the manganese include dissolution of igneous and metamorphic rock minerals, such as pyroxenes and amphiboles, and possibly decay of plant material. 

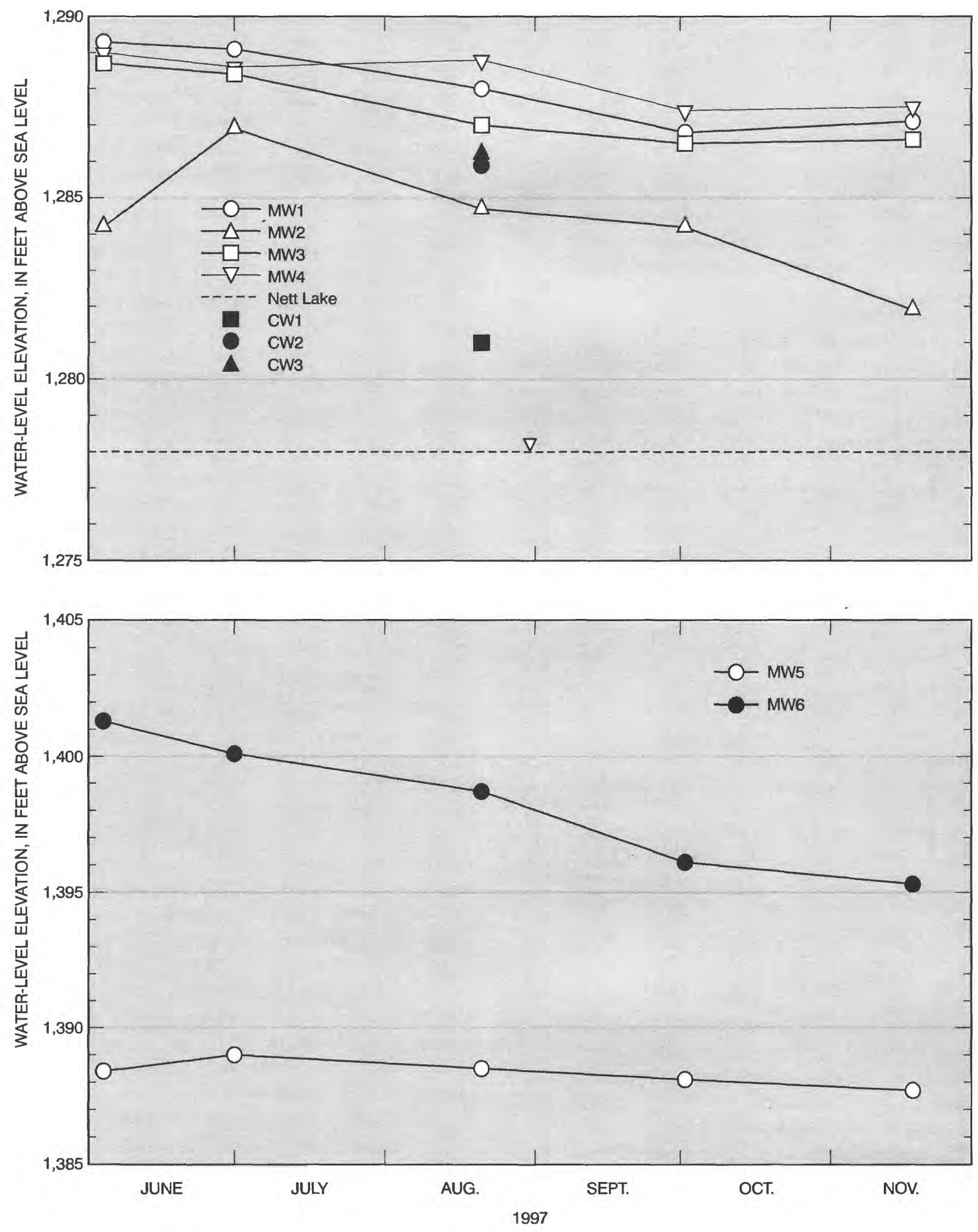

Figure 5. Water-level elevations in six monitoring wells and three community wells, Nett Lake Indian Reservation, northern Minnesota. 

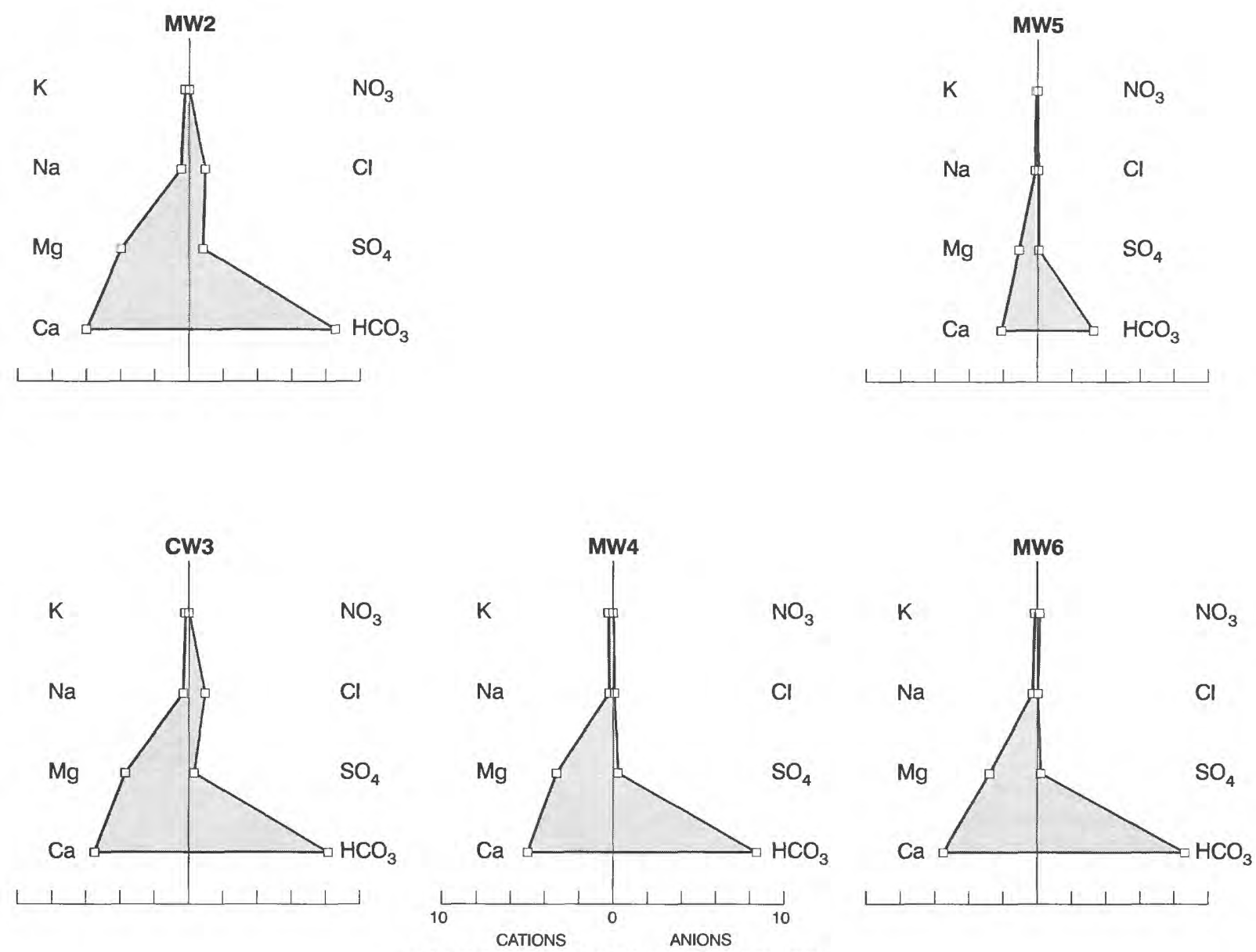

CONCENTRATIONS IN MILUEQUIVALENTS PER LITER
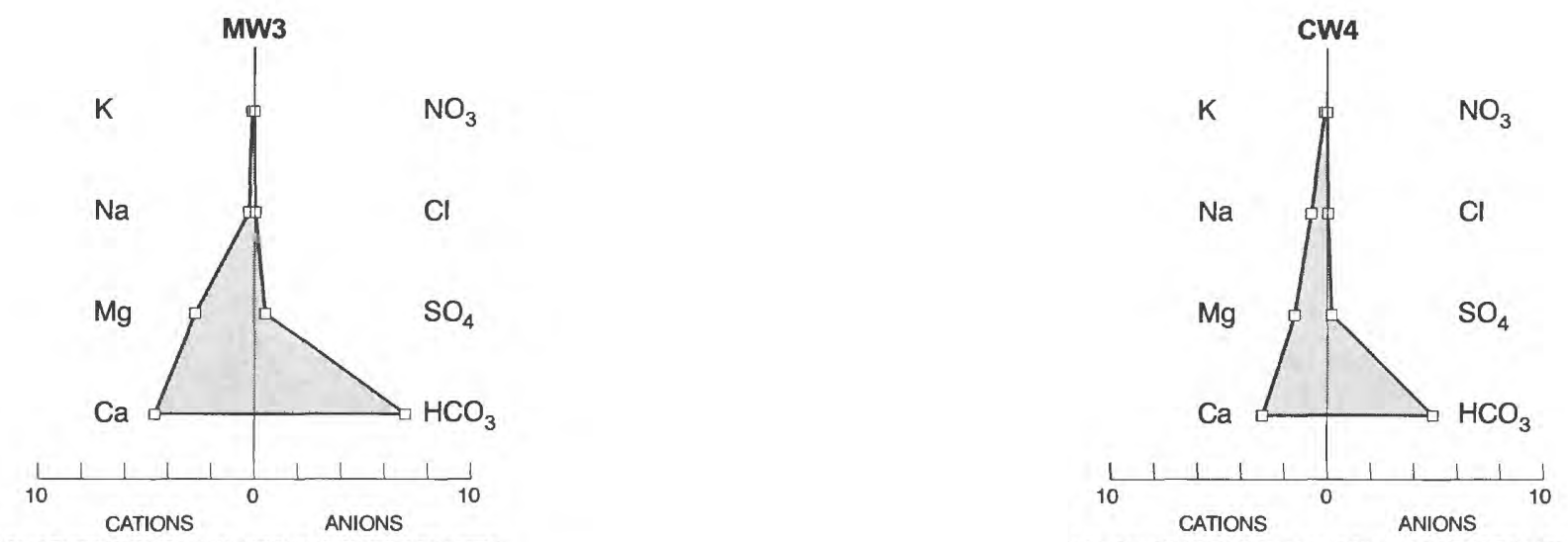

CONCENTRATIONS IN MILLIEQUIVALENTS PER UTER

CONCENTRATIONS IN MILLIEQUIVALENTS PER LITER

(number above diagram is site identifier shown on figure 3 )

Figure 6. Major-ion composition of water samples from wells completed in sand and gravel aquifers and bedrock aquifers, Nett Lake Indian Reservation, northern Minnesota, 1995-96. 
All but 3 of 63 VOCs analyzed in water from seven wells sampled had concentrations less than the MDL. The MDL for all of the VOCs analyzed in this study was $0.200 \mu \mathrm{g} / \mathrm{L}$ except for an MDL of $1.00 \mu \mathrm{g} / \mathrm{L}$ for dibromo-chloro-propane and phenols. The detected VOCs were phenols, which ranged in concentration from 2 to 3 $\mu \mathrm{g} / \mathrm{L}$ in water sampled from MW2, CW3, and MW3; benzene, which had a concentration of $0.500 \mu \mathrm{g} / \mathrm{L}$ in water sampled from MW6; and 1,1-dichloroethane, which had a concentration of $0.300 \mu \mathrm{g} / \mathrm{L}$ in water sampled from MW3 (table 4, back of the report).

Phenols are aromatic (six-carbon ring compounds) alcohols that are produced both naturally by plants and synthetically in the manufacture of a wide range of products, such as adhesives and antiseptics (McMurry, 1984). Benzene, the simplest member of aromatic compounds, is produced synthetically in the manufacture of petroleum products, solvents, plastics, and pharmaceuticals. 1,1-Dichloroethane is a twocarbon compound member of the alkane series of hydrocarbons with two attached chlorine atoms. 1,1Dichloroethane is present in solvents, paints, paint removers, gasoline, and degreasing agents (Verschueren, 1983).

Possible sources of VOCs in water from the wells sampled may include leachate from nearby closed landfills. These chemicals are frequently detected in ground water downgradient from landfills (Andrews, 1996). MW3 and MW6 are particularly vulnerable to contamination from the landfills because of their proximity (less than 50 feet) and shallow screen depths (9-14 feet for MW3; 34-39 feet for MW6). Leachate from the landfills may not have been the source of the phenols because these substances occur naturally in ground water.

MCLs have been established for 19 of the 63 VOCs analyzed in this study. Benzene, the only one of the three detected VOCs with an established MCL, had a concentration that was one order of magnitude less than its MCL of $5 \mu \mathrm{g} / \mathrm{L}$ (U.S. Environmental Protection Agency, 1996). Of the remaining 18 VOCs that had concentrations below the MDL, the MDL was less than the MCL except for di-bromo-chloro-propane, which had an MCL of $0.200 \mu \mathrm{g} / \mathrm{L}$ (table 5, back of the report). All but one of the 19 VOCs, therefore, were present at concentrations that did not exceed their respective regulatory limits. Exceedance of the MCL by di-bromochloro-propane could not be determined from the results of this study.

\section{Streamflow in the Nett Lake River Watershed}

Stage-discharge relations at the Nett Lake River and Woodduck Creek gages were affected by periodic scour and fill of the channel bed and temporary accumulations of debris in the channels. Daily mean discharge for Nett Lake River and Woodduck Creek are listed in tables 6 and 7 at the back of the report. A hydrograph of daily mean discharges is shown in figure 7. Daily mean discharge for Lost River was not determined because dam building by beavers combined with vegetation and debris in the channel resulted in a highly-variable, indeterminate relation between stage and discharge.

Drainage areas for the Nett Lake River and Woodduck Creek at the gage sites are 128 and $31.8 \mathrm{mi}^{2}$, respectively. The drainage area for Lost River at the gage site, which is about 4 miles upstream from its mouth, is 24.0 $\mathrm{mi}^{2}$. The drainage area for Lost River does not include drainage from Portage Creek, which enters Lost River downstream of the Lost River gage site (fig. 1).

Six current-meter discharge measurements were made on the Lost River (table 8, back of the report). These measurements were compared with concurrent daily discharge records for Woodduck Creek and Nett Lake River. This comparison showed that discharge in Woodduck Creek was substantially greater than discharge in Lost River on two of the six days. On those days, July 30, 1996 and August 27, 1996, discharges in Woodduck Creek were, respectively, 8.7 and 5.4 times greater than discharges in Lost River. These results were unexpected because the drainage area at the gage site for Woodduck Creek $\left(31.8 \mathrm{mi}^{2}\right)$ is only about 1.3 times larger than that for Lost River $\left(24.0 \mathrm{mi}^{2}\right)$. In contrast, on February 12, 1996, and on March 13, 1996, discharges in Lost River were about 3.8 times greater than discharges in Woodduck Creek. Results of two other measurements, made on June 19, 1996, and on November 13, 1996, show that the ratios of discharge in Woodduck Creek to Lost River were about 1:1 and $1.4: 1$, respectively, values that are similar to the ratio of the drainage areas.

The discharge measurements in Lost River, although few, indicate that the discharge in this river relative to discharge in Woodduck Creek can be variable. The commonly used assumption that discharge magnitudes in two streams that have adjacent or nearby catchments will be approximately proportional to their respective drainage areas may not apply to these watersheds. Current-meter discharge measurements may be needed to adequately determine discharge, particularly in Lost River. 


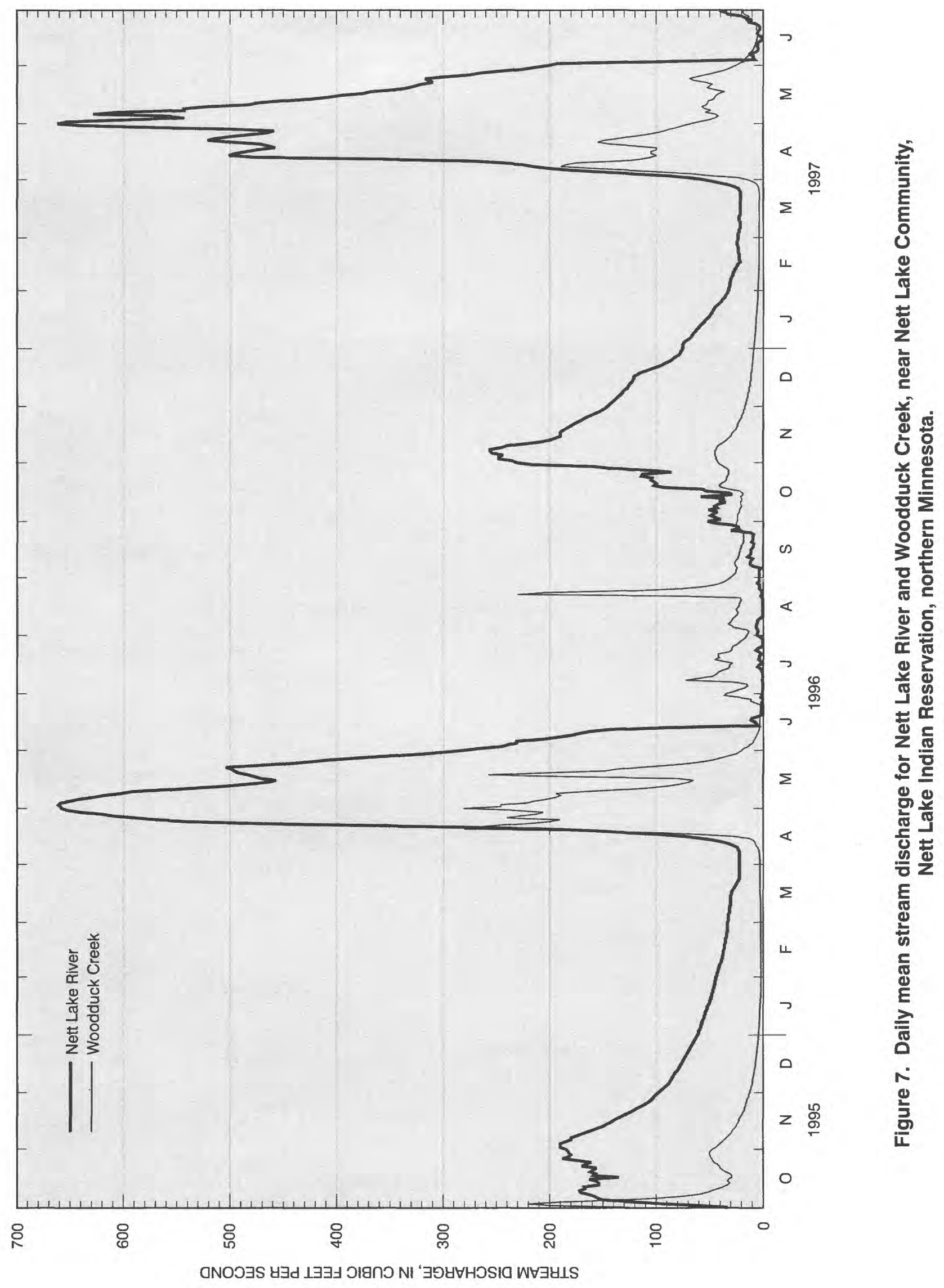




\section{Summary}

The Nett Lake Indian Reservation extends over about a $164 \mathrm{mi}^{2}$ area in northern Minnesota. About 300 people live in Nett Lake Community, about 100 people live in Palmquist Community, and a few people live in other parts of the Reservation. Water resources in the Reservation include: (1) ground water in sand and gravel aquifers and bedrock aquifers; (2) Nett Lake; (3) streams in the Nett Lake River watershed; and (4) wetlands that extend over about one-half the Reservation.

Aquifers in the Reservation consist of sand and gravel and bedrock. The buried sand and gravel aquifers are important sources of water near Nett Lake Community, where reported yields for wells completed in these aquifers are as much as $60 \mathrm{gal} / \mathrm{min}$. Reported yields for wells completed in the bedrock aquifers are as much as $34 \mathrm{gal} / \mathrm{min}$.

The Reservation is within the Little Fork River Basin. Streams that flow into and out of Nett Lake are in the Nett Lake River watershed, a subbasin of the Little Fork River Basin. Most of the streamflow into Nett Lake is from Lost River and Woodduck Creek; a small amount of streamflow into Nett Lake is from several other small streams. All streamflow from Nett Lake is to the Nett Lake River.

Water-level elevations in three monitoring wells that are located east of Nett Lake Community and completed in sand and gravel aquifers buried in till indicate a moderate hydraulic gradient of about $12 \mathrm{ft}$ per mile from a closed landfill toward three community wells. The hydraulic gradient may have been influenced by groundwater withdrawals from the community wells, which also are completed in sand and gravel aquifers buried in till. Potential movement of ground water from the closed landfill toward the community wells would be dependent on the degree of interconnection between sand and gravel lenses within the till.

The water-level elevation in a monitoring well near the shore of Nett Lake indicates ground water discharge into the lake through underlying peat. The thickness of the peat, determined from lakebed borings, is from 3 to 12 feet. The peat and underlying, tightly compacted, gray lake clay, because of their low permeability, may restrict ground-water discharge into the lake.

Two Palmquist Community wells probably are not hydraulically connected to the ground water in shallow glacial sediments in the vicinity of a closed landfill east of the community. The wells are located more than
2,000 feet away and are completed in a bedrock aquifer that underlies 124-154 feet of clay. Water-level elevations in two monitoring wells near the closed landfill suggest that local ground-water movement in the shallow glacial sediments was not toward the community wells.

The concentrations of iron and manganese in water from three and six wells sampled, respectively, exceeded their respective SMCL limits. All but 3 of 63 VOCs (volatile organic compounds) analyzed in water from seven wells sampled had concentrations less than the MDL (method detection limit) of $0.200 \mu \mathrm{g} / \mathrm{L}$ except for di-bromo-chloro-propane, which had a concentration less than its MDL of $1.000 \mu \mathrm{g} / \mathrm{L}$. The detected VOCs were phenols, benzene, and 1,1-dichloroethane. The sources of VOCs in water from the wells sampled may have been leachate from nearby closed landfills. Benzene, the only one of the three detected VOCs with an established MCL, had a concentration that was one order of magnitude less than its MCL of $5 \mu \mathrm{g} / \mathrm{L}$.

The drainage areas at gage sites on the Nett Lake River and Woodduck Creek are 128 and $31.8 \mathrm{mi}^{2}$, respectively. The drainage area of the gage site on Lost River, which is about 4 miles upstream from its mouth, is $24.0 \mathrm{mi}^{2}$. This area does not include drainage from Portage Creek, which enters Lost River downstream of the Lost River gage.

Daily mean discharge was determined for the Nett Lake River and Woodduck Creek using continuousstage recorders and stage-discharge relations. Stagedischarge relations for these streams were affected by channel scour and fill and temporary accumulation of channel debris. A usable stage-discharge relation could not be developed for the Lost River, primarily because beaver dams prevented the determination of daily mean discharge.

Streamflow in the Lost River, based on the results of six discharge measurements, was highly variable relative to flow in Woodduck Creek. Four of the six measurements showed that discharge in Lost River can be substantially greater or smaller than concurrent discharge in Woodduck Creek.

\section{References}

Andrews, W.J., 1996, Few organic compounds detected in rivers and ground water in the Upper Mississippi River Basin, Minnesota and Wisconsin: U.S. Geological Survey Fact Sheet 095-96, 2 p. 
Baker, D.G., and Kuehnast, E.L., 1978, Climate of Minnesota-Part X. Precipitation Normals for Minnesota 1941-1970: University of Minnesota Agricultural Experiment Station Technical Bulletin 314, 15 p.

Baker, D.G., Kuehnast, E.L., and Zandlo, J.A., 1985, Climate of Minnesota-Part XV. Normal Temperatures (1951-1980) and their Application: University of Minnesota Agricultural Experiment Station Technical Bulletin AD-SB 2777, 66 p.

Delin, G.N., 1986, Hydrogeology of confined-drift aquifers near the Pomme de Terre and Chippewa Rivers, western Minnesota: U.S. Geological Survey Water-Resources Investigations Report 864098, 90 p.

Fishman, N.J., and Friedman, L.C., eds., 1989, Methods for the determination of inorganic substances in water and fluvial sediments: U.S. Geological Survey Techniques of Water-Resources Investigations, book 5, chap. A1, 545 p.

Helgesen, J.O., Lindholm, G.F., and Ericson, D.W., 1976, Water resources of the Little Fork watershed, northeastern Minnesota: U.S. Geological Survey Hydrologic Investigations Atlas, HA-551, 2 sheets, scale 1:500,000.

Hem, J.D., 1985, Study and interpretation of the chemical characteristics of natural water: U.S. Geological Survey Water-Supply Paper 2254, 263 p., 3 pl.

Kennedy, E.J., 1983, Computation of continuous records of streamflow: U.S. Geological Survey Techniques of Water-Resources Investigations, book 3, chap. A13, 53 p.

Koterba, M.T., Wilde, F.D., and Lapham, W.W., 1995, Ground-water data-collection protocols and procedures for the National Water-Quality Assessment Program-Collection and documentation of water-quality samples and related data: U.S. Geological Survey Open-File Report 95-399, 113 p.

Madison, R.J., and Brunett, J.O., 1984, Overview of the occurrence of nitrate in ground water of the United States, in National Water Summary 1984: U.S.
Geological Survey Water-Supply Paper 2275, p. 93-105.

McMurry, John, 1984, Organic Chemistry: Brooks/Cole Publishing Co., Monterey, California, 167 p.

Menheer, M.A., and Brigham, M.E., 1997, Groundwater sampling methods and quality-control data for the Red River of the North Basin, Minnesota, North Dakota, and South Dakota, 1993-95: U.S. Geological Survey Water-Resources Investigations Report 96-4317, 34 p.

Norvitch, R.F., 1963, Reconnaissance geology and hydrology on the Nett Lake Indian Reservation, Minnesota: U.S. Geological Survey Open-File Report, $36 \mathrm{p}$.

Rantz, S.E., 1982, Measurement and Computation of Streamflow-Volume 2. Computation of Discharge: U.S. Geological Survey Water-Supply Paper 2175, p. 285-631.

Theis, C.V., Brown, R.W., and Meyer, R.R., 1963, Estimating the transmissivity of aquifers from the specific capacity of wells, in Bentall, R., compiler, Methods of determining aquifer permeability, transmissivity, and drawdown: U.S. Geological Survey Water-Supply Paper 1536-I, p. 331-341.

U.S. Environmental Protection Agency, 1996, Drinking water regulations and health advisories: USEPA 822-8-96-002.

Verschueren, Karel, 1983, Handbook of Environmental data on organic chemicals: Van Nostrand Reinhold, New York, New York, 1310 p. 
Supplemental Information 
Table 1. Geologic logs of six monitoring wells, five community wells, three test holes, and seven lakebed borings in Nett Lake, Nett Lake Indian Reservation, northern Minnesota, 1995-96

[BLS, below land surface; ft, feet; USGS, United States Geological Survey; --, no data]

MW1 (USGS monitoring well)

Reference point elevation (at top of PVC well casing): 1,290.34 feet above sea level Screen interval depth: $21-26$ feet BLS

\begin{tabular}{cccccc}
\hline Geologic log & Depth (ft) & Thickness (ft) & Color & Hardness \\
\hline Top soil & $0-2$ & 2 & Black & Soft \\
Clay with fine sand & $2-24$ & 22 & Gray & Hard \\
Fine sand with clay & $24-26$ & 2 & Gray & $\begin{array}{c}\text { Moderately } \\
\text { hard }\end{array}$
\end{tabular}

CW1 (Nett Lake Reservation well-locally known as Nett Lake Community well 2) Reference point elevation (at top of steel well casing): 1,299 feet above sea level Screen interval depth: 25 - 40 feet BLS

\begin{tabular}{ccccc}
\hline Geologic log & Depth $(\mathrm{ft})$ & Thickness $(\mathrm{ft})$ & Color & Hardness \\
\hline Top soil & $0-2$ & 2 & Black & Soft \\
Clay & $2-23$ & 21 & -- & Gray \\
Sand & $23-25$ & 2 & Gray & Gray \\
Clay with silt & $25-33$ & 8 & -- \\
Sand & $33-43$ & 10 & -- & Hard
\end{tabular}

MW2 (USGS monitoring well)

Reference point elevation (at top of PVC well casing): 1,297.41 feet above sea level Screen interval depth: 35 - 40 feet BLS

\begin{tabular}{ccccc}
\hline Geologic log & Depth $(\mathrm{ft})$ & Thickness $(\mathrm{ft})$ & Color & Hardness \\
\hline Top soil & $0-2$ & 2 & Black & Soft \\
Clay with sand and gravel & $2-38$ & 36 & Gray & Hard \\
Coarse sand and gravel with clay & $38-40$ & 2 & Gray & Moderately \\
hard & & -- & Very hard
\end{tabular}


Table 1. Geologic logs of six monitoring wells, five community wells, three test holes, and seven lakebed borings in Nett Lake, Nett Lake Indian Reservation, northern Minnesota, 1995-96—continued

CW2 (Nett Lake Reservation well-locally known as Nett Lake Community well 3) Reference point elevation (at top of steel well casing): 1,296 feet above sea level Screen interval depth: 46 - 50 feet BLS

\begin{tabular}{ccccc}
\hline Geologic log & Depth (ft) & Thickness (ft) & Color & Hardness \\
\hline Top soil & $0-2$ & 2 & Black & - \\
Clay with fine sand & $2-47$ & 45 & Gray & Gray \\
Sand with weathered bedrock & $47-50$ & 3 & -
\end{tabular}

CW3 (Nett Lake Reservation well-locally known as Nett Lake Community well 4) Reference point elevation (at top of steel well casing): 1,296 feet above sea level Screen interval depth: 39 - 49 feet BLS

\begin{tabular}{ccccc}
\hline Geologic log & Depth (ft) & Thickness (ft) & Color & Hardness \\
\hline Top soil & $0-2$ & 2 & Black \\
Clay with fine sand & $2-37$ & 35 & Gray & Gray \\
Fine sand with clay & $37-47$ & 10 & -- & - \\
Bedrock & 47 & --
\end{tabular}

MW3 (USGS monitoring well)

Reference point elevation (at top of PVC well casing): 1,292.86 feet above sea level Screen interval depth: 9 - 14 feet BLS

\begin{tabular}{ccccc}
\hline Geologic log & Depth (ft) & Thickness (ft) & Color & Hardness \\
\hline Top soil & $0-2$ & 2 & Black & Soft \\
Clay with sand and gravel & $2-12$ & 10 & Gray & Hard \\
Sand and gravel & $12-14$ & 2 & Gray & Moderately \\
hard & 14 & -- & Very hard
\end{tabular}


Table 1. Geologic logs of six monitoring wells, five community wells, three test holes, and seven lakebed borings in Nett Lake, Nett Lake Indian Reservation, northern Minnesota, 1995-96-continued

MW4 (USGS monitoring well)

Reference point elevation (at top of PVC well casing) altitude: $1,299.88$ feet above sea level Screen interval depth: $10-15$ feet BLS

\begin{tabular}{ccccc}
\hline Geologic log & Depth $(\mathrm{ft})$ & Thickness $(\mathrm{ft})$ & Color & $\begin{array}{c}\text { Hardness of } \\
\text { material }\end{array}$ \\
\hline Top soil & $0-2$ & 2 & Black & Soft \\
Clay with sand and gravel & $2-8$ & 6 & Gray & Hard \\
Coarse sand and gravel with clay & $8-15$ & 7 & Gray & $\begin{array}{c}\text { Moderately } \\
\text { hard }\end{array}$
\end{tabular}

MW5 (USGS monitoring well)

Reference point elevation (at top of PVC well casing): 1,412 feet above sea level Screen interval depth: $29-39$ feet BLS

\begin{tabular}{|c|c|c|c|c|}
\hline Geologic log & Depth (ft) & Thickness (ft) & Color & Hardness \\
\hline Top soil & $0-2$ & 2 & Black & Soft \\
\hline Fine to medium sand with clay & $2-9$ & 7 & Brown & $\begin{array}{c}\text { Moderately } \\
\text { hard }\end{array}$ \\
\hline Clay with sand & $7-39$ & 32 & Brown & Hard \\
\hline
\end{tabular}

MW6 (USGS monitoring well)

Reference point elevation (at top of PVC well casing): 1,417 feet above sea level

Screen interval depth: 34 - 39 feet BLS

\begin{tabular}{|c|c|c|c|c|}
\hline Geologic log & Depth (ft) & Thickness (ft) & Color & Hardness \\
\hline Top soil & $0-2$ & 2 & Black & Soft \\
\hline Clay & $2-37$ & 35 & Brown & $\begin{array}{c}\text { Moderately } \\
\text { hard }\end{array}$ \\
\hline Clay with sand & $37-39$ & 2 & Brown & $\begin{array}{c}\text { Moderately } \\
\text { hard }\end{array}$ \\
\hline
\end{tabular}


Table 1. Geologic logs of six monitoring wells, five community wells, three test holes, and seven lakebed borings in Nett Lake, Nett Lake Indian Reservation, northern Minnesota, 1995-96—continued

CW4 (Nett Lake Reservation Community well-llocally known as Palmquist Community well 1) (Reference point elevation not estimated) Open-hole interval depth BLS: 167 - 177 feet

\begin{tabular}{ccccc}
\hline Geologic log & Depth (ft) & Thickness (ft) & Color & Hardness \\
\hline Top soil & $0-2$ & 2 & Black & - \\
Clay & $2-156$ & 154 & Gray & Soft \\
Bedrock & $156-168$ & 12 & -- & Hard \\
Bedrock with shale & $168-173$ & 5 & - & Very hard \\
Bedrock & $173-177$ & 4 & -- & Very hard
\end{tabular}

CW5 (Nett Lake Reservation Community well-llocally known as Palmquist Community well 2) (Reference point elevation not estimated)

Open-hole interval depth BLS: 162 - 169 feet

\begin{tabular}{cccccc}
\hline Geologic log & Depth $(\mathrm{ft})$ & Thickness $(\mathrm{ft})$ & Color & Hardness \\
\hline Top soil & $0-2$ & 2 & Black & Brown \\
Sand & $2-21$ & 19 & 124 & Gray & -- \\
Clay & $21-145$ & 24 & -- & Very hard
\end{tabular}

Test hole 1

\begin{tabular}{cccccc}
\hline Geologic log & Depth (ft) & Thickness $(\mathrm{ft})$ & Color & Hardness \\
\hline Top soil & $0-2$ & 2 & Black & Hard \\
Clay & $2-5$ & 3 & Brown & Very hard
\end{tabular}

Test hole 2

\begin{tabular}{cccccc}
\hline Geologic log & Depth (ft) & Thickness (ft) & Color & Hardness \\
\hline Top soil & $0-2$ & 2 & Black & Hard \\
Clay & $2-13$ & 11 & Gray & Hard & Very hard
\end{tabular}


Table 1. Geologic logs of six monitoring wells, five community wells, three test holes, and seven lakebed borings in Nett Lake, Nett Lake Indian Reservation, northern Minnesota, 1995-96—continued

Test hole 3

\begin{tabular}{cccccc}
\hline Geologic log & Depth (ft) & Thickness (ft) & Color & Hardness \\
\hline Top soil & $0-2$ & 2 & Black & $\begin{array}{c}\text { Moderately } \\
\text { hard }\end{array}$ \\
Sand & & Brown & $\begin{array}{c}\text { Moderately } \\
\text { hard }\end{array}$ & Brown & Hard
\end{tabular}

Nett Lake peat boring 1

\begin{tabular}{cccccc}
\hline Geologic log & $\begin{array}{c}\text { Depth }^{1} \\
(\mathrm{ft})\end{array}$ & Thickness (ft) & Color & Hardness \\
\hline Peat & $0-7$ & 7 & Black & Soft \\
Clay & 7 & -- & Gray & Hard
\end{tabular}

Nett Lake peat boring 2

\begin{tabular}{cccccc}
\hline Geologic log & $\begin{array}{c}\text { Depth }^{1} \\
(\mathrm{ft})\end{array}$ & Thickness (ft) & Color & Hardness \\
\hline Peat & $0-12$ & 12 & Black & Soft \\
Clay & 12 & -- & Gray & Hard
\end{tabular}

Nett Lake peat boring 3

\begin{tabular}{ccccccc}
\hline Geologic log & $\begin{array}{c}\text { Depth }^{1} \\
(\mathrm{ft})\end{array}$ & Thickness (ft) & Color & Hardness \\
\hline Peat & $0-9$ & 9 & Black & Soft \\
Clay & 9 & -- & Gray & Hard
\end{tabular}


Table 1. Geologic logs of six monitoring wells, five community wells, three test holes, and seven lakebed borings in Nett Lake, Nett Lake Indian Reservation, northern Minnesota, 1995-96-continued

\section{Nett Lake peat boring 4}

\begin{tabular}{cccccc}
\hline Geologic log & $\begin{array}{c}\text { Depth }^{1} \\
(\mathrm{ft})\end{array}$ & Thickness $(\mathrm{ft})$ & Color & Hardness \\
\hline Peat & $0-3$ & 3 & Black & Soft \\
Clay & 3 & $\ldots$ & Gray & Hard
\end{tabular}

Nett Lake peat boring 5

\begin{tabular}{cccccc}
\hline Geologic log & $\begin{array}{c}\text { Depth }^{1} \\
(\mathrm{ft})\end{array}$ & Thickness $(\mathrm{ft})$ & Color & Hardness \\
\hline Peat & $0-8$ & 8 & Black & Soft \\
Clay & 8 & -- & Gray & Hard
\end{tabular}

Nett Lake peat boring 6

\begin{tabular}{cccccc}
\hline Geologic log & $\begin{array}{c}\text { Depth } \\
(\mathrm{ft})\end{array}$ & Thickness $(\mathrm{ft})$ & Color & Hardness \\
\hline Peat & $0-7$ & 7 & Black & Soft \\
Clay & 7 & - & Gray & Hard
\end{tabular}

Nett Lake peat boring 7

\begin{tabular}{cccccc}
\hline Geologic log & $\begin{array}{c}\text { Depth }^{1} \\
(\mathrm{ft})\end{array}$ & Thickness $(\mathrm{ft})$ & Color & Hardness \\
\hline Peat & $0-6$ & 6 & Black & Soft \\
Clay & 6 & -- & Gray & Hard \\
\hline
\end{tabular}

1 Depth below lakebed surface 


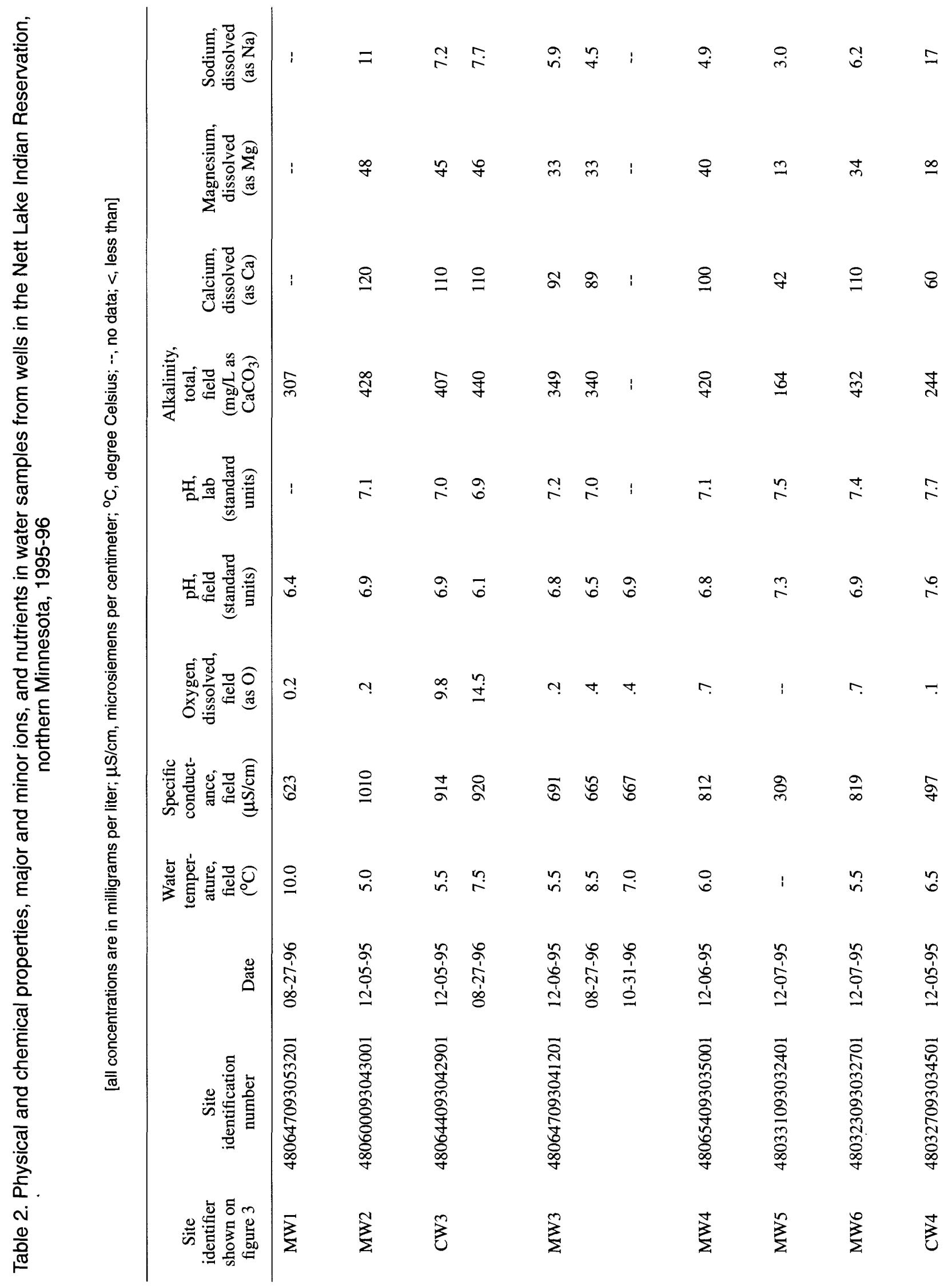




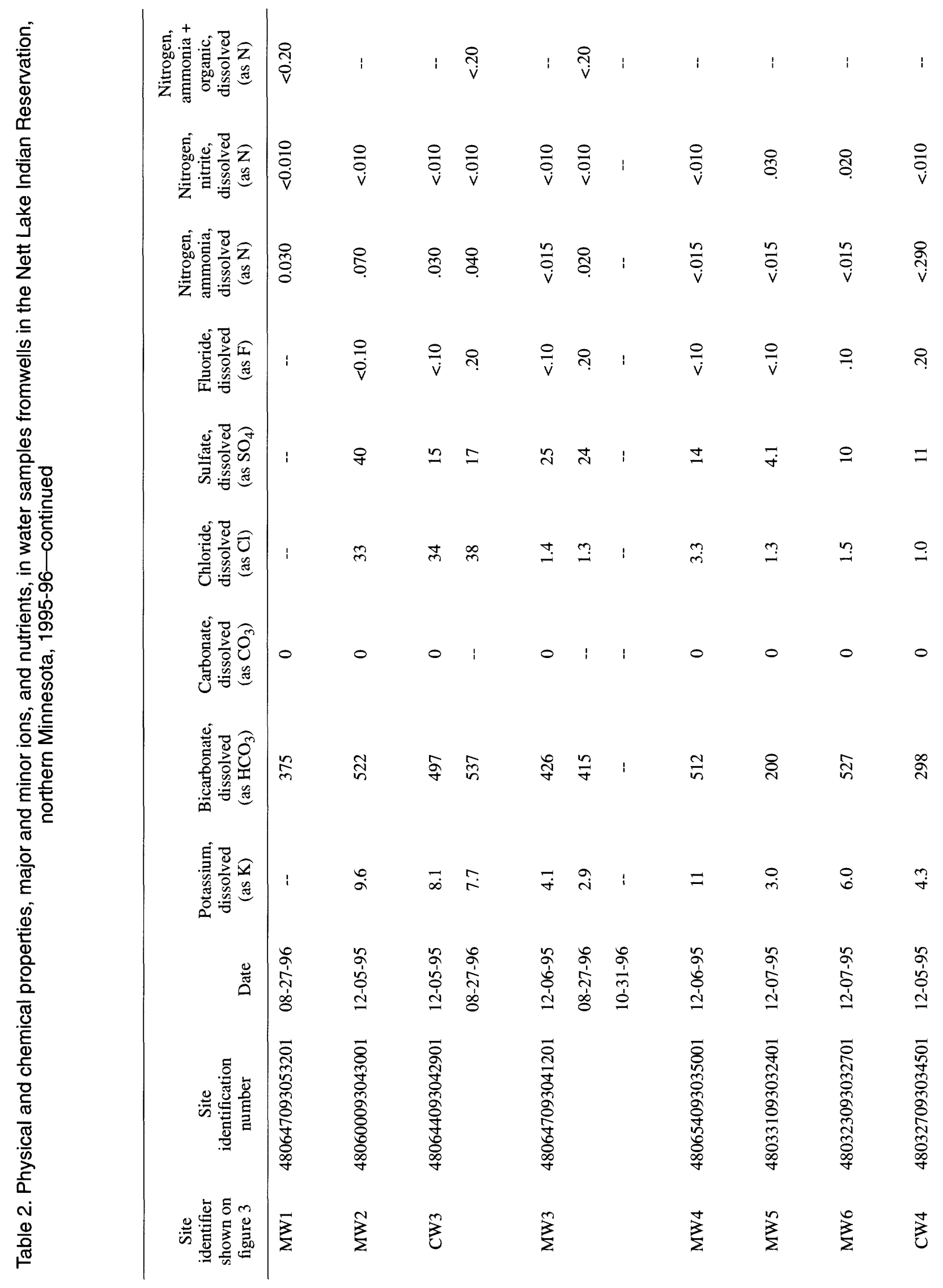




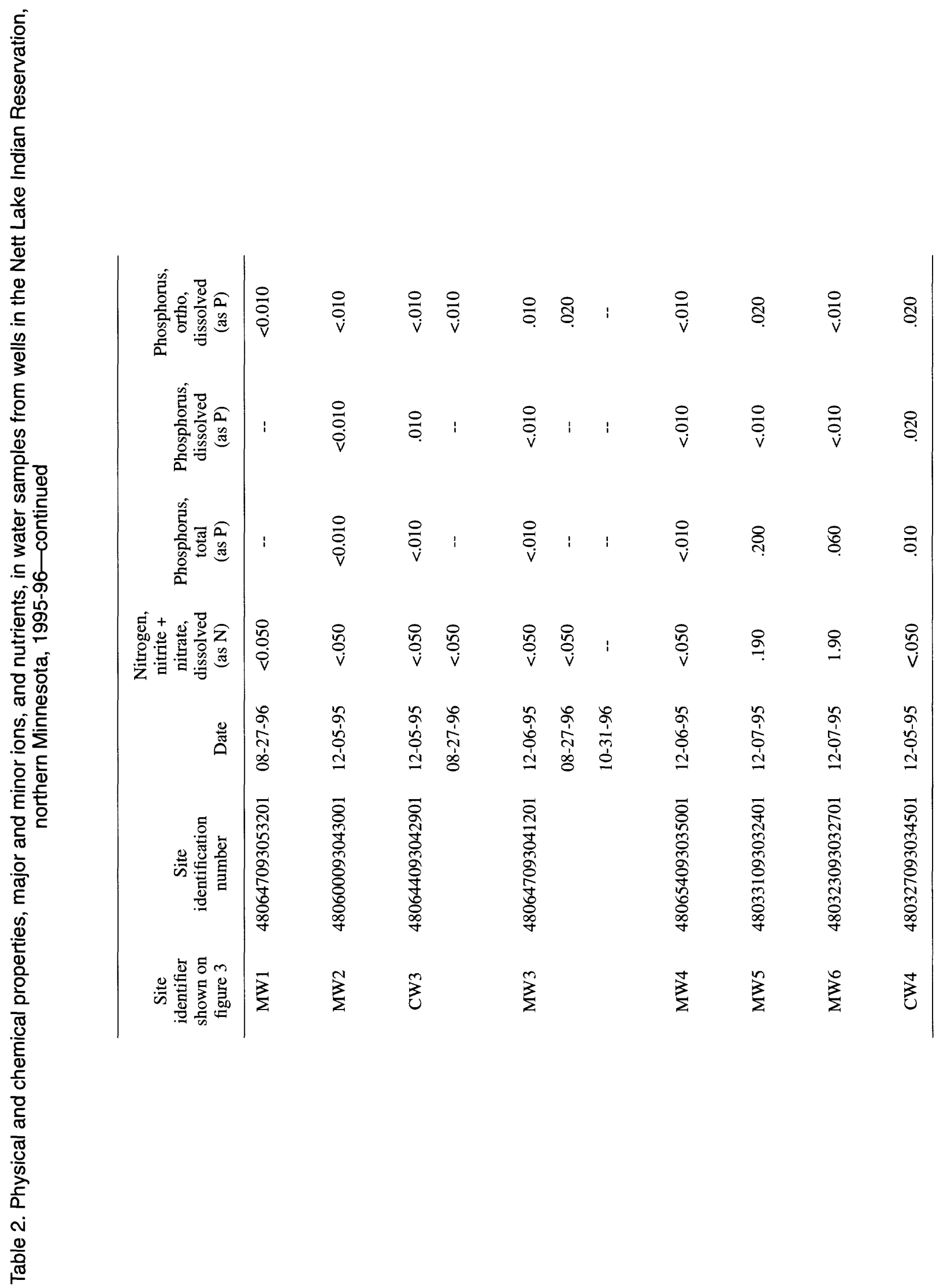




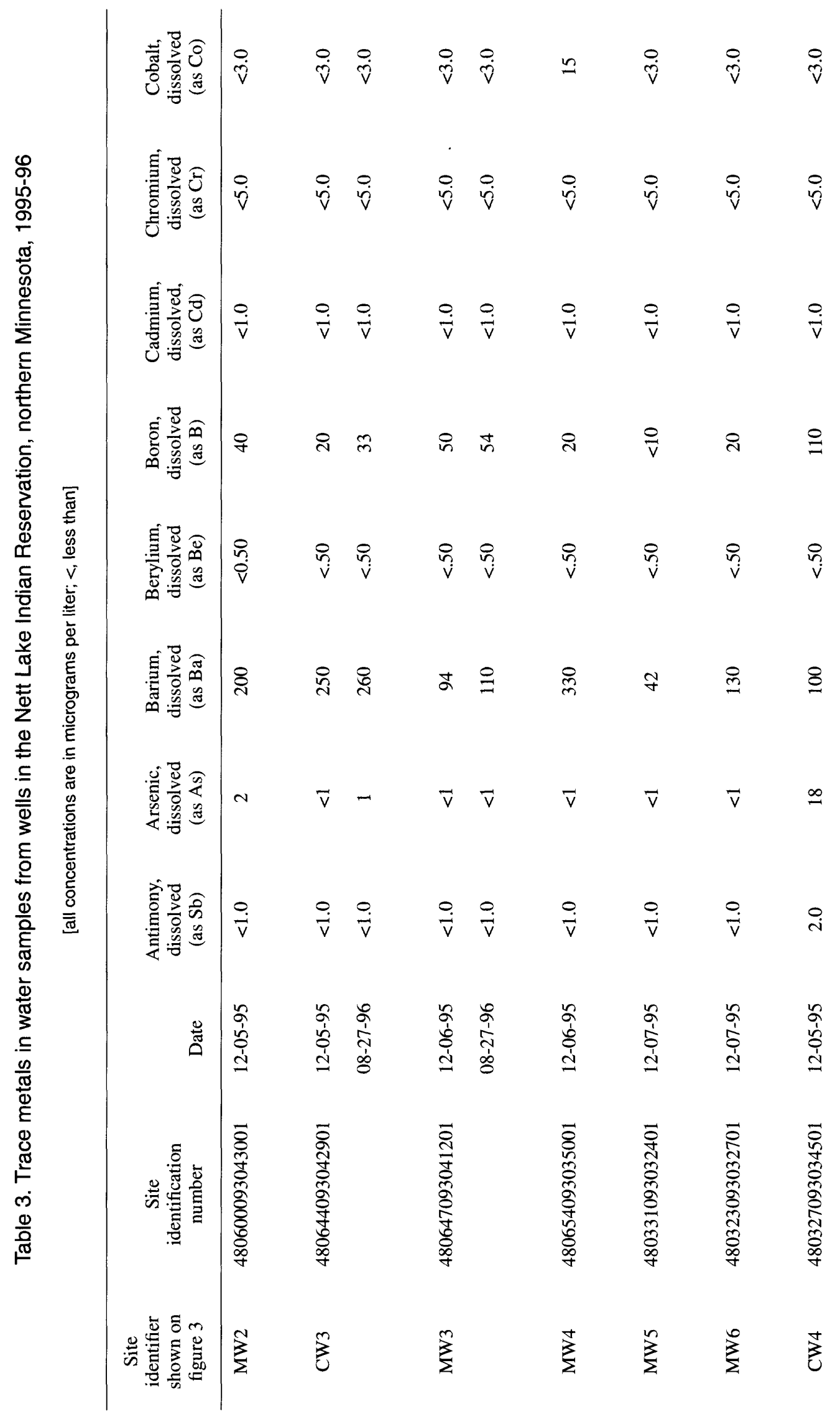




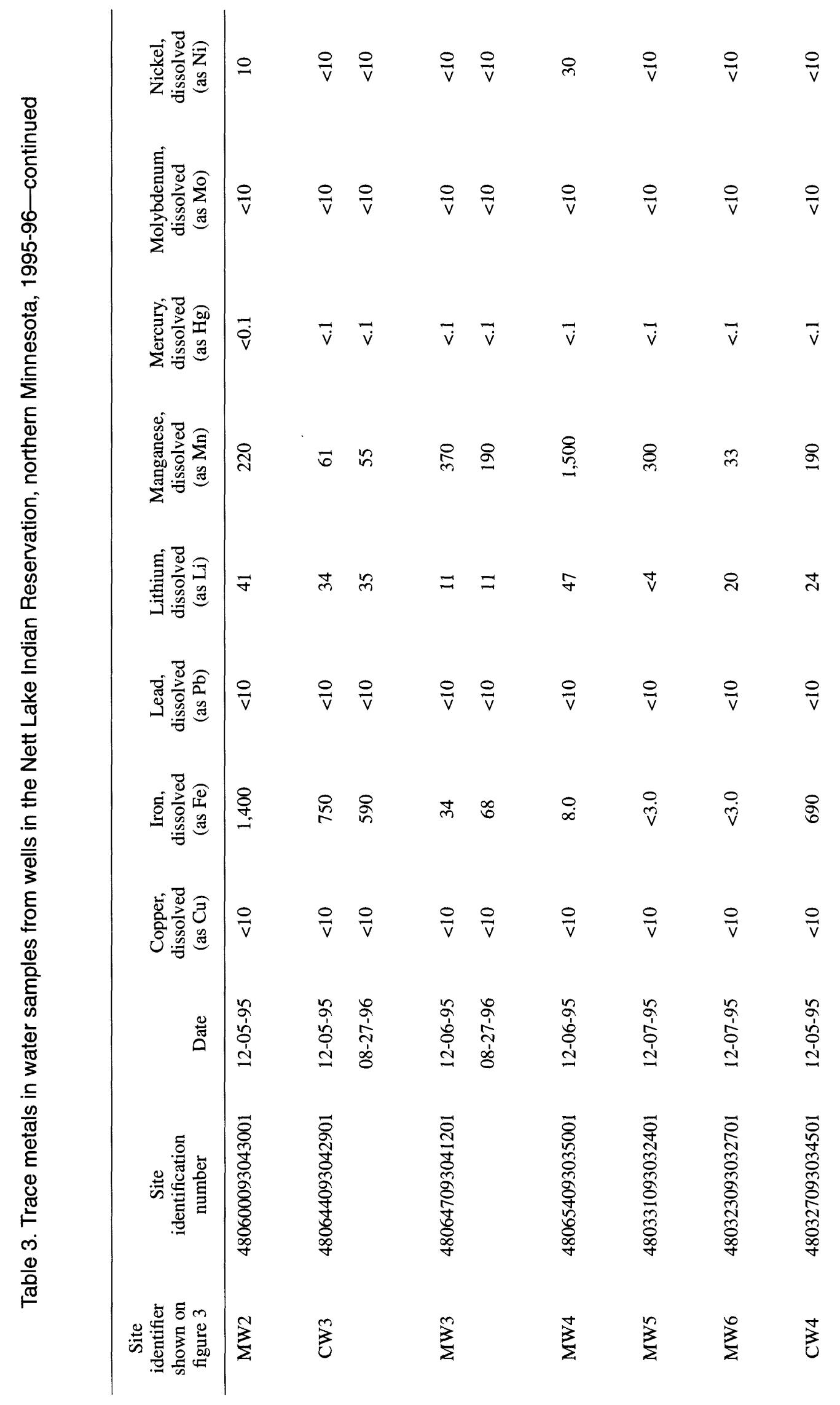




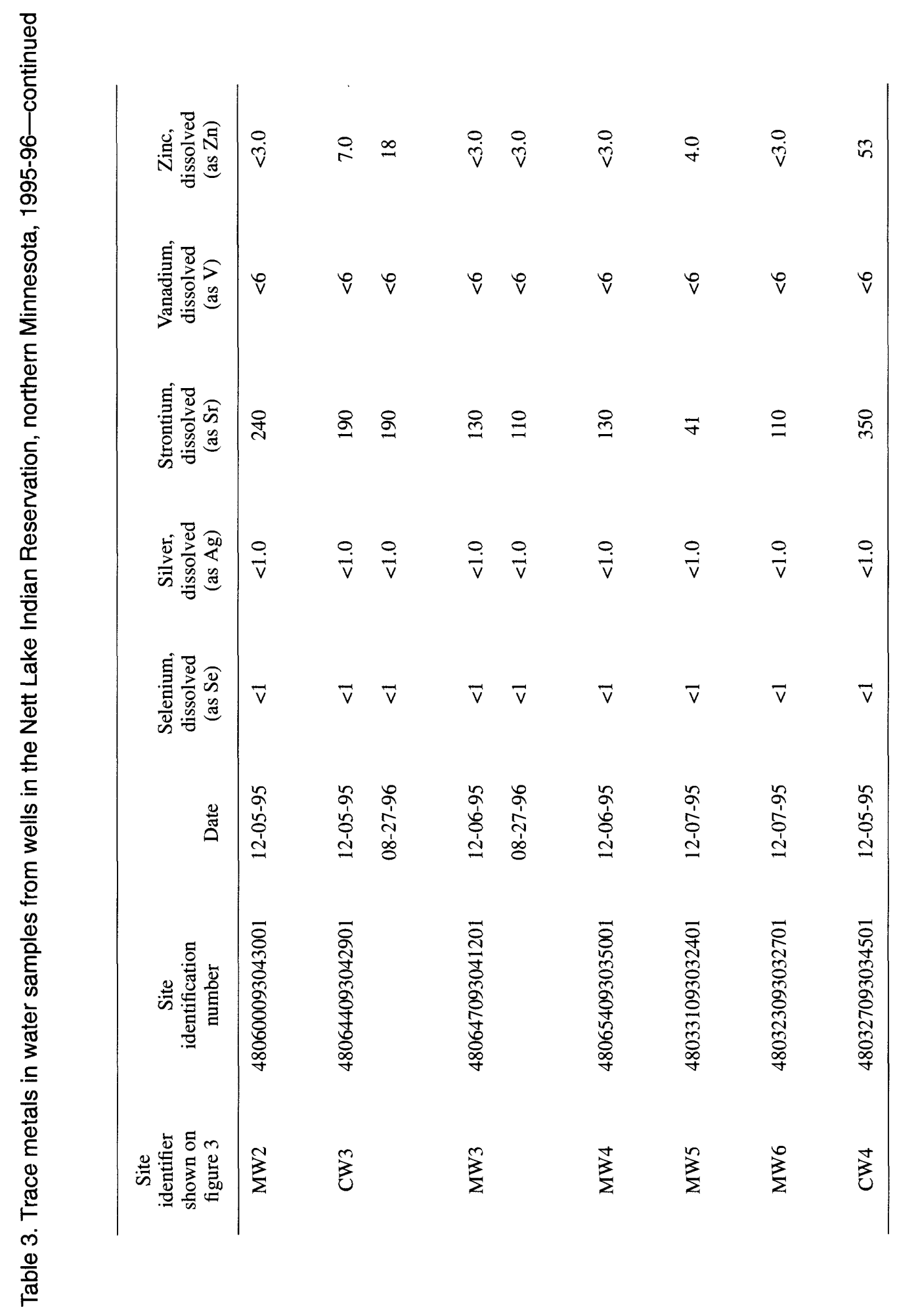


Table 4. Volatile organic compounds in water samples from wells in the Nett Lake Indian Reservation, northern Minnesota, 1995-96

[all concentrations are in micrograms per liter; <, less than; --, no data]

\begin{tabular}{|c|c|c|c|c|c|}
\hline $\begin{array}{c}\text { Site } \\
\text { identifier } \\
\text { shown on } \\
\text { figure } 1\end{array}$ & $\begin{array}{c}\text { Site } \\
\text { identification } \\
\text { number }\end{array}$ & Date & Phenols & Benzene & $\begin{array}{l}\text { 1,1-Di- } \\
\text { chloro- } \\
\text { ethane }\end{array}$ \\
\hline MW2 & 480600093043001 & $12-05-95$ & 3 & $<0.200$ & -- \\
\hline \multirow[t]{2}{*}{ CW3 } & 480644093042901 & $12-05-95$ & $<1$ & $<.200$ & -- \\
\hline & & $08-27-96$ & 2 & $<.200$ & $<0.200$ \\
\hline \multirow[t]{3}{*}{ MW3 } & 480647093041201 & $12-06-95$ & $<1$ & $<.200$ & -- \\
\hline & & $08-27-96$ & 3 & $<.200$ & .300 \\
\hline & & $10-31-96$ & -- & $<.200$ & .300 \\
\hline MW4 & 480654093035001 & $12-06-95$ & $<1$ & $<.200$ & -- \\
\hline MW5 & 480331093032401 & $12-07-95$ & $<1$ & $<.200$ & -- \\
\hline MW6 & 480323093032701 & $12-07-95$ & $<1$ & 0.500 & -- \\
\hline CW4 & 480327093034501 & $12-05-95$ & $<1$ & $<.200$ & -- \\
\hline
\end{tabular}




\section{Table 5. Volatile organic compounds not detected in water samples from wells in the Nett Lake Indian Res-}

ervation, northern Minnesota, 1995-96

[VOC, volatile organic compound; MCL, Maximum Contaminant Level; --, no MCL; *, VOC analyzed in sample water from MW2, MW3, MW4, MW5, MW6, CW3, and CW4; ${ }^{\star \star}$, VOC analyzed in sample water from CW3 and MW3]

\begin{tabular}{|c|c|}
\hline VOC & $\begin{array}{c}\mathrm{MCL} \\
(\mu \mathrm{g} / \mathrm{L})\end{array}$ \\
\hline Tertiary-butyl-methyl-ether * & -- \\
\hline Ethyl-benzene * & 700 \\
\hline Meta/para-xylene * & -- \\
\hline Toluene * & 1,000 \\
\hline Meta/Para-Xylene * & -- \\
\hline Xylene * & 1,000 \\
\hline Di-bromo-methane $* *$ & - \\
\hline Di-chloro-bromo-methane $* *$ & -- \\
\hline Carbon-tetra-chloride $* *$ & 5 \\
\hline 1,2-Di-chloro-ethane $* *$ & 5 \\
\hline Bromoform ** & - \\
\hline Chloro-di-bromo-methane $* *$ & -- \\
\hline Chloroform ** & - \\
\hline Chloro-benzene $* *$ & -- \\
\hline Chloro-ethane $* *$ & - \\
\hline Methyl-bromide ** & -- \\
\hline Methyl-chloride ** & -- \\
\hline Methylene-chloride ** & -- \\
\hline Tetra-chloro-ethylene ** & 5 \\
\hline Tri-chloro-fluoro-methane $* *$ & - \\
\hline 1,1-Di-chloro-ethylene $* *$ & 700 \\
\hline 1,1,1-Tri-chloro-ethane $* *$ & 200 \\
\hline 1,1,2-Tri-chloro-ethane $* *$ & 5 \\
\hline 1,1,2,2-Tetra-chloro-ethane $* *$ & -- \\
\hline 0 -Di-chloro-benzene $* *$ & 600 \\
\hline 1,2-Di-chloro-propane $* *$ & 5 \\
\hline 1,2-Trans-di-chloro-ethene $* *$ & 100 \\
\hline 1,3-Trans-di-chloro-propene $* *$ & -- \\
\hline 1,3 -Cis-di-chloro-propene $* *$ & -- \\
\hline 1,2,4-Tri-chloro-benzene $* *$ & 70 \\
\hline 1,3-Di-chloro-benzene $* *$ & -- \\
\hline 1,4-Di-chloro-benzene $* *$ & 75 \\
\hline Di-chloro-di-fluoro-methane $* *$ & -- \\
\hline
\end{tabular}


Table 5. Volatile organic compounds not detected in water samples from wells in the Nett Lake Indian Reservation, northern Minnesota, 1995-96-continued

\begin{tabular}{|c|c|}
\hline VOC & $\begin{array}{c}\text { MCL } \\
(\mu \mathrm{g} / \mathrm{L})\end{array}$ \\
\hline Napthalene ** & -- \\
\hline 1,1-Di-chloro-propene $* *$ & -- \\
\hline 2,2-Di-chloro-propane $* *$ & -- \\
\hline 1,3-Di-chloro-propane $* *$ & -- \\
\hline 1,2,4-Tri-methyl-benzene $* *$ & -- \\
\hline Isopropyl-benzene ** & -- \\
\hline N-Propyl-benzene $* *$ & -- \\
\hline 1,3,5-Tri-methyl-benzene $* *$ & -- \\
\hline 0 -Chloro-toluene $* *$ & -- \\
\hline P-Chloro-toluene ** & -- \\
\hline Bromo-chloro-methane $* *$ & -- \\
\hline N-Butyl-benzene $* *$ & -- \\
\hline Secondary-butyl-benzene ** & -- \\
\hline Tertiary-butyl-benzene $* *$ & -- \\
\hline P-Iso-propyl-toluene $* *$ & -- \\
\hline 1,2,3-Tri-chloro-propane ** & -- \\
\hline $1,1,1,2$-Tetra-chloro-ethane $* *$ & -- \\
\hline 1,2,3-Tri-chloro-benzene $* *$ & -- \\
\hline 1,2-Di-bromo-ethane ** & -- \\
\hline 1,1,3-Freon $* *$ & -- \\
\hline Bromo-benzene $* *$ & -- \\
\hline Di-bromo-chloro-propane $* *$ & 0.200 \\
\hline Tri-chloro-ethylene ** & 5 \\
\hline 1,2-Cis-di-chloro-ethylene ** & 70 \\
\hline Hexa-chloro-butadiene $* *$ & -- \\
\hline Styrene $* *$ & -- \\
\hline Vinyl chloride $* *$ & 2 \\
\hline
\end{tabular}


Table 6. Discharge for the Nett Lake River near Nett Lake Community, and summary statistics of the discharge, during the 1996 and 1997 water years (October 1, 1995 - September 30, 1997), Nett Lake Indian Reservation, northern Minnesota

[e, estimated; max, maximum; min, minimum; ac-ft, acre feet; cfs, cubit feet per second; cfsm, cubic feet per second per square mile; in., inches; WY, water year]

Discharge, cubit feet per second, water year October 1995 to September 1996, daily mean values

\begin{tabular}{|c|c|c|c|c|c|c|c|c|c|c|c|c|}
\hline DAY & OCT & NOV & $D E C$ & JAN & $\mathrm{F} E \mathrm{~B}$ & MAR & APR & MAY & JUN & JUL & AUG & SEP \\
\hline 1 & 33 & e185 & e98 & e61 & e 44 & e33 & e22 & 658 & 281 & .44 & 5.2 & 3.7 \\
\hline 2 & 60 & e190 & e96 & e60 & e43 & e32 & e22 & 659 & 266 & .38 & 5.1 & 3.3 \\
\hline 3 & 94 & e190 & e94 & e60 & e43 & e 32 & e22 & 661 & 245 & .11 & 4.3 & 3.3 \\
\hline 4 & 121 & e190 & e92 & e59 & e 42 & e 32 & e 22 & 659 & 239 & .09 & 5.0 & 3.4 \\
\hline 5 & 150 & e185 & e90 & e 58 & e 42 & e32 & e 22 & 650 & 231 & .06 & 6.0 & 3.5 \\
\hline 6 & 155 & e180 & e88 & e58 & e41 & e31 & e22 & 641 & 231 & .00 & 5.9 & 1.5 \\
\hline 7 & 158 & e180 & e87 & e57 & e41 & e31 & e22 & 628 & 206 & .04 & 5.7 & 9.0 \\
\hline 8 & 164 & e175 & e 86 & e57 & e 40 & e31 & e 22 & 618 & 193 & .56 & 5.0 & 12 \\
\hline 9 & 171 & e170 & e 85 & e56 & e39 & e31 & e23 & 602 & 180 & .14 & 4.8 & 12 \\
\hline 10 & 172 & e165 & e 84 & e55 & e39 & e30 & e 24 & 592 & 172 & .09 & 3.0 & 11 \\
\hline 11 & 167 & e160 & e83 & e 55 & e38 & e30 & e28 & 559 & 162 & .19 & .06 & 9.4 \\
\hline 12 & 168 & e155 & e 82 & e 54 & e38 & e30 & e 32 & 531 & 144 & .42 & .01 & 14 \\
\hline 13 & 154 & e150 & e80 & e 54 & e37 & e30 & e38 & 502 & 90 & 1.3 & .00 & 12 \\
\hline 14 & 154 & e 147 & e79 & e53 & e37 & e30 & e 47 & 484 & 4.3 & 1.5 & .00 & 11 \\
\hline 15 & 156 & e143 & e78 & e52 & e37 & e30 & e60 & 464 & 6.1 & 4.6 & .00 & 11 \\
\hline 16 & 163 & e 140 & e77 & e52 & e36 & e29 & e74 & 457 & 7.5 & 3.4 & .00 & 11 \\
\hline 17 & 135 & e137 & e76 & e51 & e36 & e29 & e95 & 471 & 11 & .15 & .00 & 9.4 \\
\hline 18 & 159 & e133 & e75 & e50 & e36 & e28 & e130 & 477 & 10 & 1.6 & .00 & 8.7 \\
\hline 19 & 157 & e130 & e74 & e50 & e35 & e 27 & e160 & 483 & 3.8 & 3.6 & .00 & 8.6 \\
\hline 20 & 162 & e127 & e73 & e49 & e35 & e26 & e200 & 492 & .01 & 3.3 & .00 & 11 \\
\hline 21 & 159 & e123 & e72 & e49 & e35 & e25 & e280 & 496 & .00 & 3.1 & .28 & 9.5 \\
\hline 22 & 156 & e120 & e71 & e48 & e34 & e24 & e380 & 499 & .00 & 1.4 & 1.8 & 9.4 \\
\hline 23 & 170 & e117 & e70 & e 48 & e34 & e23 & e480 & 504 & .00 & 3.3 & .88 & 9.5 \\
\hline 24 & 166 & e113 & e69 & e 47 & e34 & e22 & e540 & 473 & .00 & 6.4 & .46 & 8.8 \\
\hline 25 & 161 & e110 & e68 & e 47 & e33 & e22 & e570 & 445 & .00 & 4.5 & 1.5 & 12 \\
\hline 26 & 174 & e107 & e67 & e 46 & e33 & e 22 & e590 & 424 & 1.1 & .44 & 3.0 & 30 \\
\hline 27 & 188 & e105 & e66 & e46 & e33 & e22 & e610 & 405 & .49 & .05 & 2.9 & 23 \\
\hline 28 & 182 & e103 & e65 & e 45 & e33 & e22 & e620 & 378 & .16 & .03 & 3.0 & 23 \\
\hline 29 & 180 & e102 & e64 & e 45 & e33 & e22 & e640 & 351 & 1.9 & .07 & 4.9 & 29 \\
\hline 30 & 182 & e100 & e63 & e 45 & $\cdots$ & e22 & 652 & 321 & 1.2 & .09 & 3.7 & 45 \\
\hline 31 & e183 & --- & e62 & e 44 & --- & e 22 & --- & 301 & --- & 2.3 & 3.6 & --- \\
\hline TOTAL & 4754 & 4332 & 2414 & 1611 & 1081 & 852 & 6449 & 15885 & 2687.56 & 43.65 & 76.09 & 368.0 \\
\hline MEAN & 153 & 144 & 77.9 & 52.0 & 37.3 & 27.5 & 215 & 512 & 89.6 & 1.41 & 2.45 & 12.3 \\
\hline MAX & 188 & 190 & 98 & 61 & 44 & 33 & 652 & 661 & 281 & 6.4 & 6.0 & 45 \\
\hline MIN & 33 & 100 & 62 & 44 & 33 & 22 & 22 & 301 & .00 & .00 & .00 & 1.5 \\
\hline $\mathrm{AC}-\mathrm{FT}$ & 9430 & 8590 & 4790 & 3200 & 2140 & 1690 & 12790 & 31510 & 5330 & 87 & 151 & 730 \\
\hline CFSM & 1.20 & 1.13 & .61 & .41 & .29 & .21 & 1.68 & 4.00 & .70 & .01 & .02 & .10 \\
\hline & & 1.26 & .70 & 47 & 31 & 25 & 1.87 & 4.62 & 78 & .01 & .02 & 11 \\
\hline
\end{tabular}

Statistics of monthly mean data for water years 1996-1996, by water year

\begin{tabular}{|c|c|c|c|c|c|c|c|c|c|c|c|c|}
\hline MEAN & 153 & 144 & 77.9 & 52.0 & 37.3 & 27.5 & 215 & 512 & 89.6 & 1.41 & 2.45 & 12.3 \\
\hline MAX & 153 & 144 & 77.9 & 52.0 & 37.3 & 27.5 & 215 & 512 & 89.6 & 1.41 & 2.45 & 12.3 \\
\hline$(W Y)$ & 1996 & 1996 & 1996 & 1996 & 1996 & 1996 & 1996 & 1996 & 1996 & 1996 & 1996 & 1996 \\
\hline MIN & 153 & 144 & 77.9 & 52.0 & 37.3 & 27.5 & 215 & 512 & 89.6 & 1.41 & 2.45 & 12.3 \\
\hline$(W Y)$ & 1996 & 1996 & 1996 & 1996 & 1996 & 1996 & 1996 & 1996 & 1996 & 1996 & 1996 & 1996 \\
\hline
\end{tabular}

SUMMARY STATISTICS

ANNUAL TOTAL

ANNUAL MEAN

HIGHEST DAILY MEAN

LOWEST DAILY MEAN

ANNUAL SEVEN-DAY MINIMUM

INSTANTANEOUS PEAK FLOW

INSTANTANEOUS PEAK STAGE

ANNUAL RUNOFF

ANNUAL RUNOFF

ANNUAL RUNOFF

10 PERCENT EXCEEDS

50 PERCENT EXCEEDS

90 PERCENT EXCEEDS

FOR 1996 WATER YEAR

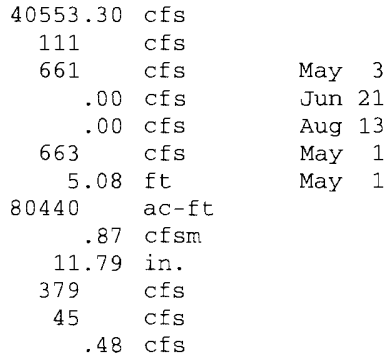


Table 6. Discharge for the Nett Lake River near Nett Lake Community, and summary statistics of the discharge, during the 1996 and 1997 water years (October 1, 1995 - September 30, 1997), Nett Lake Indian Reservation, northeastern Minnesota-continued

\begin{tabular}{|c|c|c|c|c|c|c|c|c|c|c|c|c|}
\hline DAY & $\mathrm{OCT}$ & NOV & DEC & JAN & FEB & MAR & APR & MAY & JUN & JUL & AUG & SEP \\
\hline 1 & 52 & e230 & e146 & e75 & e 32 & e23 & e 57 & 662 & 201 & --- & --- & $-\cdots$ \\
\hline 2 & 40 & e235 & e144 & e75 & e32 & e23 & 71 & 653 & 193 & $-\cdots$ & --- & -- \\
\hline 3 & 45 & 248 & e 142 & e75 & e31 & e23 & e9o & 595 & 96 & -- & -- & $\ldots$ \\
\hline 4 & 49 & 248 & e140 & e74 & e31 & e22 & e120 & 543 & 7.4 & --- & --- & --- \\
\hline 5 & 46 & 244 & e138 & e72 & e31 & e22 & e150 & 559 & 9.2 & -- & --- & -- \\
\hline 6 & 43 & 254 & e136 & e69 & e30 & e21 & e180 & 628 & 9.1 & --- & --- & $\ldots$ \\
\hline 7 & 51 & 256 & e134 & e67 & e30 & e21 & $\mathrm{e} 200$ & 605 & 13 & $\cdots-$ & --- & --- \\
\hline 8 & 43 & 256 & e132 & e66 & e29 & e21 & e215 & 543 & 6.7 & --- & --- & --- \\
\hline 9 & 45 & e245 & e131 & e65 & e28 & e21 & e225 & 543 & 4.6 & --- & --- & --- \\
\hline 10 & 42 & e 240 & e129 & e63 & e 28 & e22 & e245 & 522 & 4.2 & --- & $-\cdots$ & -- \\
\hline 11 & 35 & e225 & e127 & e62 & e27 & e22 & e275 & 482 & 5.3 & --- & --- & --- \\
\hline 12 & 41 & e209 & e126 & e60 & e26 & e22 & e 360 & 474 & 4.6 & --- & --- & --- \\
\hline 13 & 36 & $\mathrm{e} 200$ & e 125 & e59 & e25 & e21 & 478 & 453 & 5.4 & --- & --- & --- \\
\hline 14 & 58 & e195 & e123 & e57 & e 24 & e21 & 501 & 425 & 2.1 & --- & --- & --- \\
\hline 15 & 29 & e190 & e122 & e55 & e23 & e 21 & 495 & 408 & .54 & --- & --- & --- \\
\hline 16 & 32 & e190 & e121 & e 54 & e21 & e21 & 485 & 396 & 1.2 & --- & --- & $\ldots$ \\
\hline 17 & 54 & e190 & 121 & e 52 & e22 & e21 & 474 & 375 & 3.8 & --- & --- & -- \\
\hline 18 & 56 & e188 & $e 118$ & e 50 & $\mathrm{e} 22$ & e21 & 458 & 368 & 5.4 & --- & --- & --- \\
\hline 19 & 93 & e185 & e115 & e49 & e22 & e 21 & 464 & 345 & 4.4 & --- & --- & -- \\
\hline 20 & 102 & e182 & e110 & e 48 & e22 & e21 & 472 & 334 & 3.0 & --- & --- & --- \\
\hline 21 & 100 & e179 & e105 & e47 & e23 & e21 & 498 & 327 & 2.6 & --- & --- & -- \\
\hline 22 & 102 & e176 & $e 100$ & e 46 & e23 & e21 & 521 & 321 & 3.7 & --- & --- & --- \\
\hline 23 & 105 & e172 & e95 & e 45 & e23 & e21 & 514 & 310 & 6.6 &.- & -- & $\ldots$ \\
\hline 24 & 104 & e169 & e92 & e 43 & e23 & e21 & 500 & 313 & 14 & --- & --- & --- \\
\hline 25 & 114 & e166 & e8 8 & e41 & 24 & e 21 & 482 & 317 & 10 & -- & --- & $-\cdots$ \\
\hline 26 & 113 & e162 & e85 & e39 & e24 & e22 & 465 & 298 & 15 & $\ldots$ & $\ldots$ & -- \\
\hline 27 & 86 & e158 & e83 & e38 & e24 & e23 & 459 & 275 & 20 & $\ldots$ & $\ldots$ & -- \\
\hline 28 & 105 & e154 & e80 & e36 & e23 & e27 & 499 & 265 & 33 & --- & --- & --- \\
\hline 29 & 144 & e151 & e78 & e35 & --- & e32 & 586 & 246 & 35 & $\cdots$ & --- & --- \\
\hline 30 & 159 & e148 & e77 & e34 & $\ldots$ & $e 40$ & 640 & 226 & 41 & $\ldots$ & --- & --- \\
\hline 31 & e215 & --- & e76 & e33 & --- & e 48 & --- & 214 & --- & --- & --- & -- \\
\hline TOTAL & 2339 & 6045 & 3539 & 1684 & 723 & 728 & 11179 & 13025 & 760.84 & --- & -- & - - \\
\hline MEAN & 75.5 & 202 & 114 & 54.3 & 25.8 & 23.5 & 373 & 420 & 25.4 & --- & --- & --- \\
\hline $\operatorname{MAX}$ & 215 & 256 & 146 & 75 & 32 & 48 & 640 & 662 & 201 & -- & --- & $-\cdots$ \\
\hline MIN & 29 & 148 & 76 & 33 & 21 & 21 & 57 & 214 & .54 & --- & --- & --- \\
\hline $\mathrm{AC}-\mathrm{FT}$ & 4640 & 11990 & 7020 & 3340 & 1430 & 1440 & 22170 & 25840 & 1510 & $\ldots$ & -- & --- \\
\hline CFSM & .59 & 1.57 & .89 & .42 & .20 & .18 & 2.91 & 3.28 & .20 & -- & --- & $-\cdots$ \\
\hline IN. & .68 & 1.76 & 1.03 & .49 & .21 & .21 & 3.25 & 3.79 & .22 & --- & --- & $\ldots$ \\
\hline
\end{tabular}


Table 7. Discharge for Woodduck Creek near Nett Lake Community, and summary statistics of the discharge, during the 1996 and 1997 water years (October 1, 1995 - September 30, 1997), Nett Lake Indian Reservation, northern Minnesota

[e, estimated; max, maximum; min, minimum; ac-ft, acre feet; cfs, cubic feet per second; cfsm, cubic feet per second per square mile; in., inches; WY, water year]

Discharge, cubic feet per second, water year October 1995 to September 1996, daily mean values

\begin{tabular}{|c|c|c|c|c|c|c|c|c|c|c|c|c|}
\hline DAY & OCT & NOV & $\mathrm{DEC}$ & JAN & FEB & MAR & APR & MAY & JUN & JUL & AUG & SEP \\
\hline 1 & 119 & e47 & e12 & e3. 8 & e1. 8 & e1. 8 & e2.7 & 281 & 20 & 34 & 15 & 30 \\
\hline 2 & 196 & e44 & e12 & e3.7 & e1. 8 & e1.8 & e2.7 & 246 & 18 & 27 & 14 & 28 \\
\hline 3 & 221 & e42 & e11 & e3. 5 & e1.8 & e1. 8 & e2. 8 & 246 & 14 & 22 & 13 & 26 \\
\hline 4 & 187 & e40 & e11 & $\mathrm{e} 3.4$ & e1.8 & e1. 8 & $\mathrm{e} 2.8$ & 222 & 12 & 17 & 15 & 25 \\
\hline 5 & 137 & e38 & e10 & e3. 3 & e1. 8 & e1. 8 & e2.9 & 214 & 9.4 & 14 & 27 & 25 \\
\hline 6 & 99 & e36 & e9.8 & e 3.2 & e1. 8 & e1. 8 & e3.o & 202 & 8.7 & 15 & 29 & 24 \\
\hline 7 & 75 & e 34 & e9.7 & e3.1 & e1. 8 & e1. 8 & e 3.2 & 194 & 7.6 & 28 & 32 & 25 \\
\hline 8 & 60 & e 32 & $\in 9.4$ & $=3.0$ & e1. 8 & e1. 8 & e3. 5 & 190 & 6.7 & 72 & 30 & 26 \\
\hline 9 & 52 & e 30 & e9.0 & e2.9 & e1. 8 & e1.8 & e4.0 & 194 & 5.8 & 59 & 29 & 26 \\
\hline 10 & 48 & e29 & e8.7 & e2.8 & e1.8 & e1. 8 & e5.0 & 169 & 4.9 & 47 & 28 & 25 \\
\hline 11 & 42 & e28 & e8. 3 & e2.7 & e1. 8 & e1. 8 & e6. 4 & 132 & 4.0 & 44 & 26 & 23 \\
\hline 12 & 37 & e26 & e8.0 & e2. 6 & e1. 8 & e1. 8 & e7. 0 & 106 & 3.6 & 42 & 24 & 23 \\
\hline 13 & 33 & e25 & e7. 8 & e2. 5 & $\mathrm{e} 1.8$ & e1.9 & e7. 6 & 90 & 3.1 & 39 & 23 & 22 \\
\hline 14 & 31 & e24 & e7. 4 & e2. 5 & e1. 8 & e2. 0 & e9.4 & 78 & 2.8 & 33 & 24 & 22 \\
\hline 15 & 33 & e23 & e7.0 & $\mathrm{e} 2.4$ & e1.8 & e2.1 & e13 & 70 & 2.8 & 31 & 25 & 21 \\
\hline 16 & 32 & e22 & e6. 8 & e2. 3 & e1. 8 & $\mathrm{e} 2.3$ & e30 & 65 & 2.9 & 31 & 23 & 21 \\
\hline 17 & 29 & e22 & e6. 6 & e2. 3 & e1. 8 & $\mathrm{e} 2.4$ & e60 & 79 & 2.8 & 28 & 22 & 20 \\
\hline 18 & 29 & e21 & e6. 4 & $\mathrm{e} 2.2$ & e1. 8 & e2. 5 & e100 & 175 & 2.6 & 37 & 22 & 20 \\
\hline 19 & 31 & e20 & e6. 2 & e2.1 & e1. 8 & e2. 6 & e170 & 258 & 2.5 & 45 & 21 & 19 \\
\hline 20 & 35 & e19 & e6. 0 & e2.1 & e1.8 & e2.7 & e280 & 210 & 2.4 & 41 & 20 & 18 \\
\hline 21 & 38 & e18 & e5. 8 & $\mathrm{e} 2.0$ & e1. 8 & e2.7 & $\in 270$ & 149 & 2.2 & 42 & 21 & 18 \\
\hline 22 & 40 & e17 & e5. 6 & e2. 0 & e1. 8 & e2.7 & e250 & 136 & 2.1 & 42 & 76 & 18 \\
\hline 23 & 41 & e17 & e5. 4 & e2.0 & e1. 8 & e2.7 & e220 & 115 & 1.9 & 32 & 230 & 18 \\
\hline 24 & e43 & e16 & e 5.2 & e1.9 & e1. 8 & e2.7 & e200 & 91 & 1.9 & 29 & 204 & 18 \\
\hline 25 & $e 46$ & e16 & e5. 0 & e1.9 & e1. 8 & e2.7 & e190 & 70 & 1.8 & 29 & 119 & 18 \\
\hline 26 & $e 47$ & e15 & e4. 8 & e1.9 & e1. 8 & $\mathrm{e} 2.7$ & e 240 & 56 & 6.8 & 28 & 76 & 19 \\
\hline 27 & $e 48$ & e15 & e 4.6 & e1.9 & e1. 8 & e2.7 & e 230 & 46 & 11 & 24 & 56 & 22 \\
\hline 28 & $e 49$ & e14 & e 4.4 & e 1.9 & e1. 8 & $\mathrm{e} 2.7$ & 213 & 39 & 11 & 22 & 45 & 25 \\
\hline 29 & $e 50$ & e13 & e 4.3 & e1.9 & e1. 8 & $\mathrm{e} 2.7$ & 206 & 32 & 22 & 20 & 39 & 25 \\
\hline 30 & e50 & e13 & e4.1 & e1.9 & --- & e2.7 & 232 & 25 & 36 & 18 & 35 & 25 \\
\hline 31 & $e 49$ & --- & e3.9 & e1.9 & --- & $e 2.7$ & --- & 22 & --- & 16 & 32 & --- \\
\hline TOTAL & 2027 & 756 & 226.2 & 77.6 & 52.2 & 69.8 & 2967.0 & 4202 & 233.3 & 1008 & 1395 & 675 \\
\hline MEAN & 65.4 & 25.2 & 7.30 & 2.50 & 1.80 & 2.25 & 98.9 & 136 & 7.78 & 32.5 & 45.0 & 22.5 \\
\hline MAX & 221 & 47 & 12 & 3.8 & 1.8 & 2.7 & 280 & 281 & 36 & 72 & 230 & 30 \\
\hline MIN & 29 & 13 & 3.9 & 1.9 & 1.8 & 1.8 & 2.7 & 22 & 1.8 & 14 & 13 & 18 \\
\hline $\mathrm{AC}-\mathrm{FT}$ & 4020 & 1500 & 449 & 154 & 104 & 138 & 5890 & 8330 & 463 & 2000 & 2770 & 1340 \\
\hline CFSM & 2.06 & .79 & .23 & .08 & .06 & .07 & 3.11 & 4.26 & .24 & 1.02 & 1.42 & .71 \\
\hline IN. & 2.37 & .88 & .26 & .09 & .06 & .08 & 3.47 & 4.92 & .27 & 1.18 & 1.63 & .79 \\
\hline
\end{tabular}

Statistics of monthly mean data for water years 1996-1996, by water year

\begin{tabular}{|c|c|c|c|c|c|c|c|c|c|c|c|c|}
\hline MEAN & 65.4 & 25.2 & 7.30 & 2.50 & 1.80 & 2.25 & 98.9 & 136 & 7.78 & 32.5 & 45.0 & 22.5 \\
\hline MAX & 65.4 & 25.2 & 7.30 & 2.50 & 1.80 & 2.25 & 98.9 & 136 & 7.78 & 32.5 & 45.0 & 22.5 \\
\hline (WY) & 1996 & 1996 & 1996 & 1996 & 1996 & 1996 & 1996 & 1996 & 1996 & 1996 & 1996 & 1996 \\
\hline MIN & 55.4 & 25.2 & 7.30 & 2.50 & 1.80 & 2.25 & 98.9 & 136 & 7.78 & 32.5 & 45.0 & 22.5 \\
\hline (WY) & 1996 & 1996 & 1996 & 1996 & 1996 & 1996 & 1995 & 1996 & 1996 & 1996 & 1996 & 1996 \\
\hline
\end{tabular}

SUMMARY STATISTICS

ANNUAL TOTAL

ANNUAL MEAN

HIGHEST DAILY MEAN

LOWEST DAILY MEAN

ANNUAI SEVEN-DAY MINIMUM

INSTANTANEOUS PEAK FLOW

INSTANTANEOUS PEAK STAGE

INSTANTANEOUS LOW FLOW

ANNUAL RUNOFF (AC-FT)

ANNUAL RUNOFF (CFSM)

ANNUAL RUNOFF (INCHES)

10 PERCENT EXCEEDS

50 PERCENT EXCEEDS

90 PERCENT EXCEEDS
FOR 1996 WATER YEAR

$\begin{array}{clll}13689.1 & \text { cfs } & & \\ 37.4 & \text { cfs } & & \\ 281 & \text { cfs } & \text { May } 1 \\ 1.8 & \text { cfs } & \text { Feb } 1 \\ 1.8 & \text { cfs } & \text { Feb } 1 \\ 322 & \text { cfs } & \text { May 1 } \\ 11.52 & \text { ft } & \text { Apr 20 } \\ 1.7 & \text { cfs } & \text { Jun 25 } \\ 27150 & \text { ac-ft } & & \\ 1.18 & \text { cfsm } & & \\ 16.01 & \text { in. } & & \\ 116 & \text { cfs } & & \\ 18 & \text { cfs } & & \\ 1.8 & \text { cfs } & & \end{array}$


Table 7. Discharge for Woodduck Creek near Nett Lake Community, and summary statistics of the discharge, during the 1996 and 1997 water years (October 1, 1995 - September 30, 1997), Nett Lake Indian Reservation, northeastern Minnesota-continued

\begin{tabular}{|c|c|c|c|c|c|c|c|c|c|c|c|c|}
\hline DAY & $\mathrm{OCT}$ & NOV & $\mathrm{DEC}$ & JAN & FEB & MAR & APR & MAY & JUN & JUL & AUG & SEP \\
\hline 1 & 24 & e 42 & e17 & e8. 3 & e4. 5 & e3. 4 & e15 & 67 & 25 & $\ldots$ & --- & --- \\
\hline 2 & 24 & e 43 & e16 & e 8.1 & e4. 4 & e 3.4 & e25 & 59 & 22 & $\ldots$ & --- & -- \\
\hline 3 & 24 & $e 44$ & e16 & e7. 9 & e4. 3 & e3. 4 & $e 50$ & 50 & 18 & $-\cdots-$ & --- & $\cdots$ \\
\hline 4 & 24 & e 44 & e15 & e7. 7 & e 4.2 & e 3.4 & e66 & 45 & 16 & --- & --- & --- \\
\hline 5 & 23 & e 45 & e15 & e7. 5 & e4.2 & e3. 4 & e94 & 42 & 16 & --- & --- & --- \\
\hline 6 & 22 & e 45 & e14 & e7. 3 & e4.1 & e3. 4 & e125 & 45 & 14 & $\ldots$ & $-\cdots$ & --- \\
\hline 7 & 22 & e45 & e14 & e7.1 & e4.0 & e3. 4 & e160 & 54 & 13 & --- & --- & -- \\
\hline 8 & 21 & e44 & e14 & e7.0 & e3.9 & e 3.4 & e190 & 49 & 11 & $\ldots$ & --- & --- \\
\hline 9 & 20 & e43 & e13 & e 6.8 & e3.9 & e3. 4 & e185 & 55 & 9.5 & --- & --- & --- \\
\hline 10 & 21 & $e 42$ & e13 & e6.7 & e 3.8 & e 3.4 & e 175 & 57 & 8.5 & --- & --- & -- \\
\hline 11 & 21 & e39 & e13 & e6. 6 & e3. 8 & e 3.4 & e130 & 53 & 7.7 & $\ldots$ & --- & --- \\
\hline 12 & 20 & e36 & e12 & e6. 5 & e3.7 & e3. 4 & e115 & 52 & 7.1 & $\ldots$ & $\ldots$ & $\ldots$ \\
\hline 13 & 20 & e 34 & e12 & e6. 4 & e 3.6 & e3.4 & e105 & 51 & 6.2 & -- & $\cdots$ & --- \\
\hline 14 & 21 & e32 & e12 & e6. 3 & e3. 6 & e3. 4 & e 100 & 46 & 5.6 & $\ldots$ & --- & -- \\
\hline 15 & 19 & e30 & e11 & e6. 2 & e3. 5 & e3. 4 & e105 & 45 & 5.5 & --- & --- & $\ldots$ \\
\hline 16 & 19 & e29 & e11 & e6.1 & e3. 5 & e3. 4 & e105 & 44 & 5.2 & --- & -- & --- \\
\hline 17 & 22 & e28 & e11 & e6.0 & e 3.4 & e3. 4 & e 100 & 41 & 4.9 & --- & -- & --- \\
\hline 18 & 32 & e26 & e11 & e5.9 & e3. 4 & e3. 4 & e100 & 36 & 5.5 & --- & --- & -- \\
\hline 19 & 39 & e25 & e11 & e5.8 & $\mathrm{e} 3.4$ & e 3.4 & 120 & 45 & 4.8 & --- &.-- & -- \\
\hline 20 & 41 & $e 24$ & e10 & e5.7 & e3. 4 & $\mathrm{e} 3.4$ & 145 & 52 & 6.0 & --- & --- & -- \\
\hline 21 & 39 & $e 24$ & e10 & $e 5.6$ & e3. 4 & e3. 4 & 155 & 50 & 5.9 & --- & $-\cdots$ & $-\cdots$ \\
\hline 22 & 36 & e23 & e9.9 & e5. 5 & e 3.4 & e 3.4 & 149 & 48 & 5.6 & --- & $-\infty$ & $\ldots$ \\
\hline 23 & 34 & $\mathrm{e} 22$ & e9.7 & e5. 4 & e3. 4 & e3. 4 & 135 & 54 & 6.3 & --- & -- & -- \\
\hline 24 & 34 & e21 & e9. 5 & e5. 3 & e 3.4 & e3. 5 & 124 & 65 & 12 & -- & --- & $\ldots$ \\
\hline 25 & 33 & $\mathrm{e} 20$ & e9. 4 & e5. 2 & $\mathrm{e} 3.4$ & $e 3.6$ & 111 & 69 & 16 & --- & --- & -- \\
\hline 26 & 32 & e20 & e9. 3 & e 5.0 & e3. 4 & e 3.8 & 100 & 62 & 16 & $\cdots$ & --- & $\ldots$ \\
\hline 27 & 32 & e19 & $\mathrm{eg} .2$ & e4.9 & $\mathrm{e} 3.4$ & e4.0 & 93 & 54 & 13 & --- & --- & $-\cdots$ \\
\hline 28 & 32 & e18 & e9.0 & e4. 8 & e 3.4 & $e 4.5$ & 87 & 46 & 17 & --- & $\ldots$ & $\ldots$ \\
\hline 29 & 34 & e18 & $e 8.8$ & e4.7 & --- & $e 5.5$ & 80 & 39 & 19 & --- & --- & $\ldots$ \\
\hline 30 & e37 & e17 & e8. 6 & e 4.7 & -- & e7.0 & 74 & 33 & 18 & --- & $\ldots$ & $\ldots$ \\
\hline 31 & $e 40$ & --- & e8. 5 & e4. 6 & --- & e10 & --- & 29 & --- & $\cdots$ & --- & $\ldots$ \\
\hline TOTAL & 862 & 942 & 362.9 & 191.6 & 103.8 & 120.1 & 3318 & 1537 & 340.3 & --- & $\ldots$ & $-\cdots$ \\
\hline MEAN & 27.8 & 31.4 & 11.7 & 6.18 & 3.71 & 3.87 & 111 & 49.6 & 11.3 & --- & --- & $-\cdots$ \\
\hline MAX & 41 & 45 & 17 & 8.3 & 4.5 & 10 & 190 & 69 & 25 & $-\cdots$ & $\ldots$ & $\ldots$ \\
\hline MIN & 19 & 17 & 8.5 & 4.6 & 3.4 & 3.4 & 15 & 29 & 4.8 & $\cdots$ & --- & $\ldots$ \\
\hline$A C-E T$ & 1710 & 1870 & 720 & 380 & 206 & 238 & 6580 & 3050 & 675 & --- & --- & $\ldots$ \\
\hline CFSM & .87 & .99 & .37 & .19 & .12 & .12 & 3.48 & 1.56 & .36 & --- & --- & $-\cdots$ \\
\hline IN. & 1.01 & 1.10 & .42 & .22 & .12 & .14 & 3.88 & 1.80 & .40 & --- & --- & $-\cdots$ \\
\hline
\end{tabular}

Statistics of monthly mean data for water years 1996-1996, by water year

$\begin{array}{lrlllllllrrrr}\text { MEAN } & 46.6 & 28.3 & 9.50 & 4.34 & 2.74 & 3.06 & 105 & 92.6 & 9.56 & 32.5 & 45.0 & 22.5 \\ \text { MAX } & 65.4 & 31.4 & 11.7 & 6.18 & 3.71 & 3.87 & 111 & 136 & 11.3 & 32.5 & 45.0 & 22.5 \\ \text { (WY) } & 1996 & 1997 & 1997 & 1997 & 1997 & 1997 & 1997 & 1996 & 1997 & 1996 & 1996 & 1996 \\ \text { MIN } & 27.8 & 25.2 & 7.30 & 2.50 & 1.80 & 2.25 & 98.9 & 49.6 & 7.78 & 32.5 & 45.0 & 22.5 \\ \text { (WY) } & 1997 & 1996 & 1996 & 1996 & 1996 & 1996 & 1996 & 1997 & 1996 & 1996 & 1996 & 1996\end{array}$

SUMMARY STATISTICS

FOR 1996 CALENDAR YEAR

WATER YEARS $1996-1997$

ANNUAL TOTAL

ANNUAL MEAN

HIGHEST ANNUAL MEAN

LOWEST ANNUAL MEAN

HIGHEST DAILY MEAN

LOWEST DAILY MEAN

ANNUAL SEVEN-DAY MINIMUM

INSTANTANEOUS PEAK FLOW

INSTANTANEOUS PEAK STAGE

ANNUAL RUNOFF

ANNUAL RUNOFF

ANNUAL RUNOFF

$\begin{array}{rlll}12846.8 & \text { cfs } & & \\ 35.1 & \text { cfs } & & \\ & & & \\ 281 & \text { cfs } & \text { May } & 1 \\ 1.8 & \text { cfs } & \text { Feb } & 1 \\ 1.8 & \text { cfs } & \text { Feb } & 1 \\ & & & \\ 25480 & \text { ac-ft } & & \\ 1.10 & \text { ac-ft } & & \\ 15.03 & \text { in } & & \\ 82 & \text { cfs } & & \\ 19 & \text { cfs } & & \\ 1.8 & \text { cfs } & \end{array}$

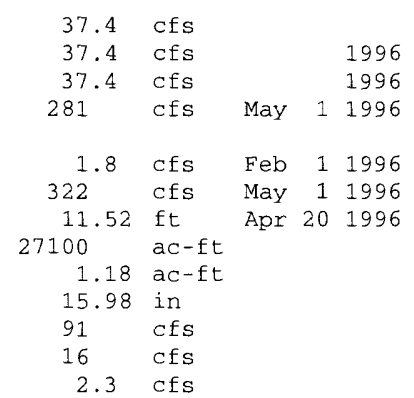


Table 8. Instantaneous streamflow in Lost River, and daily mean streamflow in Woodduck Creek and Nett Lake River, near Nett Lake Community, Nett Lake Indian Reservation, northern Minnesota $\left[\mathrm{ft}^{3} / \mathrm{s}\right.$, cubic feet per second]

\begin{tabular}{cccc}
\hline Date & $\begin{array}{c}\text { Lost River near } \\
\text { Nett Lake } \\
\left(\mathrm{ft}^{3} / \mathrm{s}\right)\end{array}$ & $\begin{array}{c}\text { Woodduck } \\
\text { Creek near Nett } \\
\text { Lake } \\
\left(\mathrm{ft}^{3} / \mathrm{s}\right)\end{array}$ & $\begin{array}{c}\text { Nett Lake River } \\
\text { near Nett Lake } \\
\left(\mathrm{ft}^{3} / \mathrm{s}\right)\end{array}$ \\
\hline February 12,1996 & 6.92 & 1.8 & 38 \\
March 13, 1996 & 6.99 & 1.8 & 30 \\
June 19, 1996 & 2.58 & 2.5 & 3.8 \\
July 30, 1996 & 2.07 & 18 & 0.09 \\
August 27, 1996 & 10.4 & 56 & 2.9 \\
November 13, 1996 & 23.7 & 34 & 200 \\
\hline
\end{tabular}

